IFN Working Paper No. 876, 2011

\title{
Employment Protection Reform, Enforcement in Collective Agreements and Worker Flows
}

Fredrik Heyman and Per Skedinger 


\title{
Employment Protection Reform, Enforcement in Collective Agreements and Worker Flows
}

\author{
Fredrik Heyman $^{*}$ and Per Skedinger ${ }^{* *}$ \\ ${ }^{*}$ Research Institute of Industrial Economics (IFN), \\ Box 55665, SE-102 15 Stockholm, Sweden \\ ${ }^{* *}$ Research Institute of Industrial Economics (IFN), \\ Box 55665, SE-102 15 Stockholm, Sweden \\ and \\ Centre for Labour Market and Discrimination Studies, \\ Linnaeus University, Växjö, Sweden \\ fredrik.heyman@ifn.se \\ per.skedinger@ifn.se
}

\begin{abstract}
We analyse a reform of notice periods for employer-initiated separations in Sweden, which reduced the notice periods for newly hired older workers substantially but implied minor or no changes in the advance notices for younger workers. The reform was initiated at different times depending on collective agreement. These circumstances provide ample opportunity for the identification of its effects. Our findings indicate heterogeneous effects on hirings and separations across collective agreements. A salient feature of the results is that the estimated effects increase with the treatment dose, i.e., the size of the reduction in notice periods across different age groups.
\end{abstract}

Keywords: Employment protection; Hirings; Separations; Collective agreements; Matched employer-employee data

JEL Classification: J23; J63; J14; J52; K31

\footnotetext{
\# We thank Daniel Metzger, Martin Olsson, Fabiano Schivardi, two anonymous referees and seminar participants at the Research Institute of Industrial Economics (IFN), the IAB workshop "Increasing Labor Market Flexibility - Boon or Bane?” in Nuremberg, Germany, the 6th Nordic Summer Institute in Labor Economics in Torshavn, Faroe Islands, and the 23rd EALE Conference in Pafos, Cyprus, for helpful comments. We also thank Selva Baziki, Aron Berg and Sara Fogelberg for excellent research assistance. Financial support from the Marianne and Marcus Wallenberg Foundation (first author) and the Jan Wallander and Tom Hedelius Foundation (second author) is gratefully acknowledged.
} 


\section{Introduction}

Employment protection legislation may be enforced in different ways. One type of differential enforcement results from the explicit design of the legislation, while another type is not defined by the letter of the law. The former typically stipulates differential treatment across groups of workers or types of firms. For example, in several countries employment protection legislation is less stringent in small firms. The other guise of differential enforcement is more elusive in its character, relating to implementation in collective agreements and enforcement in the judiciary, but is not necessarily of lesser importance for the effects of the legislation.

Several studies exploiting partial reforms targeted towards small firms have added to the growing evidence that more stringent legislation reduces job and worker flows and examine a variety of other outcomes. ${ }^{1}$ However, little is known about the effects of differential enforcement of employment protection legislation that is not defined by the letter of the law, presumably due to the lack of data. Fraisse, Kramarz and Prost (2011) and Okudaira (2008) exploited the variations in judicial discretion across regions. Fraisse et al. (2011) examined various indicators characterizing the enforcement of labour regulation by labour courts and Okudaira (2008) considered the assignment of judges to Japanese prefectures. Their conclusion is that enforcement matters. When legislation is applied in a more stringent way, its effects on labour market outcomes, such as employment and job flows, are stronger.

Our study incorporates aspects of both types of differential enforcement as we combine the evaluation of a partial reform in Sweden targeted towards a specific age group with information on the more difficult-to-observe enforcement of the same reform in collective agreements. To the best of our knowledge, this paper is the first one to use detailed information on both partial reform and on enforcement across collective agreements to examine the effects of employment protection legislation. ${ }^{2}$ Our hypothesis is that stricter enforcement of the legislation entails stronger effects.

Partial employment protection reforms have been introduced in many countries to improve the labour market prospects for older workers. In Sweden, legislative changes in the Employment Protection Act (EPA) in 1997 reduced the firing costs for employees aged 45 and over with the explicit purpose of increasing the job-finding probabilities and lowering unemployment among older workers. The prereform rules regarding the terms of notice for employer-initiated separations were based on the age of the employee, whereas the new rules are based on tenure. For newly hired, older workers, the reform implied a shorter notice period. The change 
was substantial for the oldest age group: a reduction in advance notice from six months to one month, equivalent to 42 percent (5/12) of an annual salary. For younger employees, smaller or no reductions were introduced. Partial reforms in other countries with similar aims have typically used layoff taxes as the policy instrument, with higher taxes imposed on firms dismissing older workers.

The EPA reform in 1997 has several attractive properties that make it suitable for evaluating the effects of employment protection. First, the reform was targeted towards older workers, so younger workers can be used as controls. Our prediction, in line with conventional theory, is that shorter notices of termination increase the probability of hiring among older workers. Second, because notice periods were reduced by varying degrees among workers aged $25-44$, ranging from 1 to 4 months, and not reduced at all among the youngest (aged 18 - 24), a stronger test of the hypothesis is possible. We expect the probability of hiring to increase monotonically with the treatment dose. Third, the possibility for employers and unions to opt out of the legislation provides another source of identification on which we have collected extensive data. In some collective agreements, the changes in the EPA were implemented with a delay of several years, so some of the older workers were not subject to treatment in 1997 and thus form an additional suitable control group.

Conventional theory not only predicts that hirings will increase with shorter notice periods, but also that separations should increase. We therefore tested for the effect on separations, using the same methodology as described above. The theoretical prediction regarding employment is ambiguous. To the extent that hirings increase more than firings, employment increases. However, the EPA reform was designed in such a way that only workers recruited after 1997 were subject to the new rules regarding notice periods. The old rules continue to apply to workers hired before 1997 who have remained with the firm. Because the remaining workers were not subject to the reductions in advance notice, we expect the reform to have a larger effect on hirings than on separations, at least in the short run.

In contrast to the EPA reform, the idea behind many partial employment protection reforms in other countries has been to make it more difficult for firms to dismiss workers in the protected group. For France, Behaghel, Crépon and Sedillot (2008) find perverse effects of layoff taxes. The hiring probability for older workers was reduced, and no benefits in the form of fewer dismissals were achieved. Similar results have been demonstrated by Acemoglu and Angrist (2001) concerning legislation in the United States aimed at protecting disabled workers. In their analysis 
of layoff taxes for the elderly in Austria, Schnalzenberger and Winter-Ebmer (2009) obtained more encouraging results: the policy reduced layoffs among workers in the targeted group, but these effects were thwarted by the substitution of younger workers for older ones at large firms.

Our data on hirings and separations originate from a large register-based matched employer-employee data set from Statistics Sweden covering the period 1990 - 2005. For each individual in the data set, we observe notice periods (measured in months) based on information from the relevant collective agreements and the EPA (if applicable). Advance notice is based on the age and/or tenure, depending on the period and the collective agreement, which differs for manual and non-manual workers in the same industry. We also have ample information on other individual and firm variables likely to influence worker turnover.

We begin our empirical investigation by calculating the expected discounted firing costs, before and after the reforms of advance notice, for workers hired at different ages, taking into account the probability that the worker is laid off during employment spells that are allowed to last up to 20 years. Our calculations show that the reforms entailed a substantial reduction in expected firing costs for older workers, and that these costs were actually also affected for young workers, but only by a modest increase. Simply measuring advance notice periods for workers of different ages before and after a reform may thus not be sufficient to induce a difference-indifference design if firms take into account the expected discounted firing costs, even though the impact on the control group of young workers turns out to be all but inconsequential in our case.

We then proceed with the econometric analysis, using various age groups as treatment and controls in a difference-in-difference setting. Our findings indicate heterogeneous reform effects across collective agreements. Despite differences in terms of dynamics and size, a positive effect on hirings is found for all agreements. With the exception of manual workers in engineering, our results also show an increase in separations, indicating an increase in employment turnover. The risk of separation depends not only on the worker's expected firing cost, but also on where the worker is ranked in the distribution of firing costs of all workers in the firm. We find that reform effects are more pronounced among workers with a short relative notice period than among those with a longer one. Thus the ranking within the distribution of firing costs matters. As far as we know, this aspect of employment protection has not been explored in previous empirical research. A salient feature of 
the results is that the estimated effects on hirings and separations increase with the treatment dose, i.e., the size of the reduction in months of the notice periods across different age groups.

\section{Labour Market Reforms in 1997}

An important feature of employment protection legislation in Sweden is that it is optional, implying that parts of the legislation can be undone in collective agreements between employers and trade unions. The possibility to deviate from the legislation through collective agreements applies to rules regarding notice, which means that it cannot be taken for granted that legislative changes in the EPA gain legal force in all sectors of the labour market.

In this section, we discuss the reform of advance notice in the EPA and its implementation in collective agreements and calculate the consequences for the expected discounted firing costs. We also describe other labour market reforms in 1997 that could impinge on our results.

The Reform of Advance Notice and Its Implementation in Collective Agreements Comprehensive legislation regarding employment protection in Sweden was introduced in the Employment Protection Act (EPA) of 1974. Before the new legislation in 1974, the legal system of employment protection was based almost exclusively on collective agreements between employers and trade unions and the application of case law. The rules regarding notice periods in the EPA were based on the age of the employee and not on tenure (as was the case in most collective agreements at the time). The legislators argued that older workers needed special protection. Rules based on tenure were seen as detrimental to labour mobility in this group because seniority capital would be lost for workers changing jobs (Regeringens proposition, 1973:129). According to the EPA, layoffs should be based on the last-infirst-out principle, and the seniority capital accumulated by older workers cannot be transferred to a new employer.

By 1996, the views among legislators regarding advance notice for older workers had changed completely. Age-based notice periods were considered counterproductive for older workers. Shorter advance notice, it was argued, would increase 
the propensity for employers to hire older workers (Regeringens proposition, 1996/97:16). One reason behind the change of focus from labour mobility to new hirings was the rise in unemployment since 1974. Figure 1 shows the diverging patterns of unemployment for older and younger persons in the years preceding the reform. In the wake of the economic crisis of the early 1990s, unemployment rates started to decline for the young in 1993, whereas rates continued to increase for older persons up to 1997.

- Figure 1 about here -

The new bill was presented to the Swedish Parliament (Riksdag) on October 24, 1996. The reform of the notice periods gained legal force on January 1, 1997. The full details of the reform are presented in Table 1. The pre-reform rules were based on the age of the employee, with a scale starting from a one-month advance notice for employees younger than 25 and ending with a maximum of a six-month notice period for employees aged 45 or older. Rules in the new legislation were based on tenure. Employees with tenure shorter than two years were entitled to a notice period of one month, while the rules stipulated up to six months of advance notice for employees with tenure of at least 10 years. No changes in the notice period for employeeinitiated separations, which is one month, were enacted in the reform.

- Table 1 about here -

A long period of transition occurred before the law became effective for all workers. The old rules continued to apply to workers employed with the same firm after January 1, 1997. Because the EPA was optional, collective agreements between employers and trade unions could deviate from the EPA. Thus, only newly hired workers were initially affected by the legal changes and only in certain areas of the labour market because the specific implementation could vary, depending on the agreement.

The EPA reform could potentially induce substitution across age groups. However, the Swedish reform implied only small differences in advance notice across close age groups - one month - so the employers' gain from substitution should be limited. 
Table 2 provides an overview of the implementation of the new legislation regarding notice periods in the collective agreements (more details can be found in the Appendix, Table A.1). ${ }^{3}$ We consider agreements for both manual and non-manual workers in engineering, construction and retail. These agreements are among the largest agreements in the labour market.

- Table 2 about here -

Our agreements either implement the legislation regarding advance notice directly or supplants it, which makes the interpretation of the enforcement in the collective agreements straightforward. ${ }^{4}$ Before the reform of the legislation, two agreements followed the rules according to the law rather closely, namely those for manual workers in engineering and retail. The other agreements set up their own rules, based on the age of the employee (manual construction workers) or on a combination of age and tenure (non-manuals in engineering and construction). The changes in the EPA in 1997 were implemented in all of the agreements but at different points in time. In the Engineering Agreement for manual workers the rules were implemented on January 1, 1997, while they were adopted with a delay of up to four years in other agreements. For non-manual workers in engineering, the rules were implemented on February 1, 2001. Manual workers in construction are covered by three agreements, with new rules introduced during 2000 and 2001. Workers in retail are covered by a substantial number of different agreements, depending on the type of products or services sold; however, for manual workers in this sector, almost all of the agreements specify the same rules regarding notice periods. The reform date for these workers was July 1, 2001. The rules for non-manual workers are much more heterogeneous in this respect and have not been included in the table.

Table 2 begs the question why the collective agreements were so diverse with respect to notice periods before the reforms. We do not try to answer this question in the paper. Instead, we take the diversity for granted and use this source of variation to identify the effects of employment protection legislation. Another question relates to the differences in the timing of reform implementation across agreements. The age structure among employees in retail (with many young workers) could have made it less pressing to implement the reform in that sector, but the slow implementation for non-manuals in engineering (with considerably older workers on average) does not fit this explanation. ${ }^{5}$ 
For workers in firms not covered by the collective agreements, the EPA applies. In Sweden, approximately 90 percent of employees and virtually all larger firms are covered by such agreements.

In principle, workers and employers may anticipate employment protection reform and adjust their behaviour accordingly in various ways. Prior to this reform, older workers could seek employment in other firms before January 1, 1997 to take advantage of the provisionary rules requiring longer notice periods for hirings that occurred before that date. Employers could potentially gain by dismissing relatively young workers with long tenure earlier, before the reform. However, because most young workers have short tenure and long-tenured workers are protected by the seniority rules in the EPA, employers had limited benefits from anticipating the reform. The reform was likely not anticipated in a way that could affect our results because the bill was presented to the Riksdag on October 24, 1996, and it was uncertain until October whether the major trade union for manual workers, LO, would be able to successfully block the reform, according to newspaper accounts at the time (see Sedvallson, 1996). We regard the risk of anticipation to be larger for the subsequent implementations of the reform for non-manual workers in engineering and in construction and retail.

\section{Consequences of the Reform of Advance Notice for Expected Discounted Firing Costs}

To estimate the expected discounted costs due to the reform, we constructed an index based on the formula proposed by Heckman and Pagés-Serra (2000). This index measures the expected dismissal costs at the time a worker is hired:

$$
\operatorname{Index}_{j, s, t}=\sum_{i=1}^{T} \beta^{i} \delta_{j}^{i-1}\left(1-\delta_{j}\right)\left[b_{j, s, t+i}+(1-a) S_{t+i}^{j c}+a S_{t+i}^{u c}\right]
$$

where $j$ denotes the collective agreement that the worker is bound by, $s$ is the age group of the worker, $t$ is the time period (years), $T$ is the maximum tenure of a worker, $\beta$ is the discount factor, $\delta$ is the probability of not being laid off, $b$ is the advance notice (in months), $a$ is (in our specific formulation and interpretation ${ }^{6}$ ) the probability that the dismissal is considered as unjust by a court, $S^{j c}$ is the severance 
pay associated with dismissals with just cause, and $S^{u c}$ is the severance pay in case a court rules that the dismissal is without just cause. ${ }^{7}$

Like Heckman and Pagés-Serra (2000), we assume a discount rate of 8 percent and a common layoff rate across agreements of 12 percent, which implies a value of 0.88 for $\delta$. Later, we relax the assumption of a common layoff rate. We use US data on layoff rates, and not our own Swedish data, since we wish to capture structural layoffs rates in the absence of (stringent) employment protection and the Swedish data reflect the impact of this legislation. The industry-specific layoff rates for the United States imply values for $\delta$ of 0.84 for engineering, 0.80 for retail and 0.56 for construction. ${ }^{8}$ The minimum tenure with a firm is assumed to be 1 year, and the maximum 20 years. The severance pay associated with dismissals with just cause is zero in Sweden; therefore, the second term within the second parenthesis drops out. The severance pay for dismissals without just cause (denoted as damages awarded to the employee in the EPA) is defined in monthly salaries by the EPA and is dependent on tenure and age (see Lunning and Toijer, 2006). ${ }^{9}$ The probability of a dismissal being judged as unjust is initially assumed to be zero (i.e., a=1) and then arbitrarily set to 1 percent $(\mathrm{a}=0.99)$.

In Table 3, the expected discounted costs of a dismissal are defined before and after the reform as well as for two types of worker: one hired at age 20 and another at age 45. Advance notice is defined according to the respective agreements and the EPA (see Table 1 and Table A.1 in the Appendix). The simple differences between the pre- and post-reform costs are calculated for each worker type and can be interpreted as the individual reform effect for the two types. The difference-indifference (d-i-d) in the table refers to the above difference for a 45-year-old worker versus the difference for a 20 -year-old worker and can be viewed as the relative reform effect across age groups. The inclusion of severance pay for dismissals without just cause in the two rightmost columns is merely for illustrative purposes and does not affect any of the reform effects because the rules regarding severance pay have remained unchanged in the pre- and post-reform periods.

- Table 3 about here -

Table 3 reveals that the firing costs for both older workers and for younger workers were affected by the reform. However, the reform effect is modest for the 20- 
year-olds, amounting to a cost increase of about $0.3-0.7$ of a monthly salary, depending on the assumed parameter values. For the 45-year-olds, a substantial decrease in costs, ranging between 1.9 and 3.9 monthly salaries, was found. The difference-in-difference between the two types of worker thus varies between -2.6 and -4.2. Note that post-reform firing costs are equal across age groups with $a=1$, since the notice period became independent on age for newly hired workers. The difference-in-difference is larger (in absolute value) in the construction sector; otherwise, the variation across agreements and industries is small. The values indicate that the reform had a significant impact on the expected discounted firing costs for older workers in relation to young workers. The cost-decreasing effect amounts to 22 - 35 percent of an annual salary, depending on the agreement.

The effect of a higher layoff rate on the total expected costs is ambiguous (not shown in Table 3). In industries with a relatively high layoff rate (for example in construction), the expected firing costs are higher in the short term. However, because the probability that a worker remains employed also decreases faster, the short-term firing costs are countered by lower expected costs in the longer run. To the extent that firing costs increase with age and tenure, the long-term cost-reducing effect is strengthened.

Other Labour Market Reforms and Collectively Agreed Employment Protection Schemes Two partial reforms of particular importance to labour market outcomes for older workers were introduced on January 1, 1997. One reform concerned stricter rules for the eligibility of disability insurance for 60 - 64-year-olds. Labour market reasons (in combination with medical reasons) for granting pensions were no longer allowed for this group. As pointed out by Saint-Paul (2009), an increase in the retirement age could increase hirings among some older workers because hiring costs at a given age are spread over a longer employment period. The other reform was part of the legislative changes in the EPA and made it easier for firms to deviate from seniority rules (last-in-first-out) when dismissing older workers due to a lack of work. The new law stipulated that firm-level agreements between employers and trade unions that exempt workers older than 57.5 years from the seniority rules no longer needed approval by a union at the central level. To check the sensitivity of our results to these reforms that could affect worker flows for workers between the ages of 57 and 64 , we estimated separate regressions for the age group $45-59$, the members of 
which were the primary target group of the 1997 EPA reform but were not subject to the other reforms.

A reform of fixed-term contracts in 1997 allowed employers to hire temporary workers without objective reason, but the maximum duration of such work was not changed. This reform may have increased hirings and firings disproportionately among young workers, since temporary work is less prevalent in the older age groups. Loosening of regulations for temporary workers may also have had repercussions on the employment of permanent workers, since the two categories are to some extent substitutes. However, we do not have information on the type of employment contract in our data. Because of the reform it is possible that we underestimate the effects on workers flows in the regressions with younger workers as control.

Special employment protection schemes (omställningsavtal) in case of layoffs have also been collectively negotiated on a broader scale for manual and non-manual workers in the private and public sectors (Andersson, Fölster and Skedinger, 2002, Martinson, 2005). In relation to the EPA and the industry-specific collective agreements, these schemes imply longer notice periods and the possibilities to deviate from seniority rules. Another important difference regards financing. The schemes are financed through insurance fees, payable by firms with membership in the relevant employer organisation. Unlike the costs associated with advance notice, risk pooling exists across firms. In 2005, seven so-called job security councils (Trygghetsråd) administered the schemes. Two of the councils cover workers in the collective agreements considered in our study, Trygghetsfonden TSL, founded in 2004 for manual workers in the private sector, and TRR Trygghetsrådet for non-manuals in the same sector, established in 1974. Because these firing costs are borne by the councils and not by the individual employer, the age profiles of hirings and separations should not be affected by the special employment protection schemes. ${ }^{10}$

\section{Data}

Our study is based on a matched employer-employee database from Statistics Sweden that contains detailed data on Swedish firms and establishments linked with a large sample of individuals. Individual, plant and firm-level-based data are linked together with unique tracking numbers. Information on the implementation of notice periods at the industry level is added from the collective agreements for manual and non-manual 
workers. In the empirical part of the paper, we focus on hirings and separations in two large industries: engineering and retail. ${ }^{11}$ In each of these sectors, we distinguish between different collective agreements covering the different types of workers within each industry.

The database consists of the following parts. First, the individual data contain individual wage statistics based on Statistics Sweden's annual salary surveys, supplemented by information from a series of data registers. The dataset encompasses information on more than two million individuals for the period 1990 - 2005 (accounting for roughly 50 percent of the labour force) and contains information on workers' wages, education, work hours, occupation codes, sector codes, demographic data, etc. Second, the financial statistics (FS) include detailed firm-level data. The included variables are value added, capital stock (book value), number of employees, wage bill, ownership status, profits, sales and industry affiliation.

Finally, the plant-level data contain detailed information at the plant level, such as employee demographics, salaries, education and codes for company mergers, closures, formations and operational changes.

For each individual in the data set, we observe the notice period (in months), based on information in the relevant collective agreement and in the EPA (if applicable). The notice period is based on age and/or tenure, depending on the period and the collective agreement, which differs for manual and non-manual workers in the same industry.

Our main focus is hirings and separations. The construction of the indicator variable for new hirings is based on workers that are newly employed in a firm that is present in the data the year before. This condition is imposed to reduce the risk of classifying a worker as being newly employed due to the firm being new in the data set, although not being a start-up. Similarly, we define a worker separation as observing an individual at time $t$ who is not present in the same firm at time $t+1$, although the firm is continuing at $t+1$. $^{12}$

Another restriction is that we do not include firms with very large changes in the observed number of employees between two consecutive time periods. ${ }^{13} \mathrm{We}$ exclude these large-scale hirings and separations from the empirical analysis because we do not want extraordinary events, such as massive layoffs or company mergers to interfere with the results. Our restrictions imply that the analysis will be based on continuing firms and will not take into account the impact of firm start-ups and firm closures. 
The variable definitions and descriptive statistics are presented in Tables A.2 and A.3 in the Appendix. ${ }^{14}$ In Table A.3, the means and standard deviations are shown for the three different samples of individuals: manuals in engineering, nonmanuals in engineering and manuals in retail. Workers aged 45 - 64 represent between 33 and 42 percent of the workforce in engineering but only one-fifth of the workforce in retail. Turnover, measured across all age groups, is also markedly higher in retail than in engineering.

Figures $2-4$ depict hirings and separations by age groups in engineering and retail. Worker flows are highly cyclical, especially for hirings and among young workers and manuals. The year preceding the reform is indicated by a vertical line. Retail firms implemented the reform for manual workers rather late in the year (July); therefore, the year 2001 is likely to reflect the effects of both regimes. For this reason, we eliminated the year 2001 from the data in the regressions for these workers and use 2002 as the start of the post-reform period.

- Figures 2 and 3 about here -

Figures 2 - 3 highlight the trade-off that we confront when analysing the effects of the reform. On the one hand, the differential in the treatment dose is largest when comparing outcomes for the 45 - 64-year-olds to those of the youngest age group, 18 - 24 (for which the right-hand side scale applies). This observation supports using the youngest group as the control. On the other hand, because cyclicality in worker flows is quite pronounced among the youngest, the older age groups are more similar to the 45 - 64-year-olds in this respect. We have chosen to focus our analysis on using 25 - 29-year-olds as the control - a compromise solution to the trade-off but we also test the sensitivity of our estimates to using several other age groups. The age groups $25-29$ and $45-64$ are highlighted with grey in the figures. Pre-reform trends for 25 - 29-year-olds are roughly similar to those for workers aged 45 - 64 years in most cases, at least regarding the 2-year period preceding the reform (with the exception of manuals in retail in Figure 3.c). For manual workers in engineering, we experiment with using the same age group (45 - 64-year-olds) among nonmanuals in the same industry as the control. According to Figure 4, pre-1997 trends are parallel for the two worker categories. ${ }^{15}$ In engineering, both younger manuals and same-aged non-manuals may indirectly be affected by the reform for older manual workers, through the production process and other spillover effects. 
- Figure 4 about here -

\section{Econometric framework}

Our empirical strategy is to use a difference-in-difference approach to compare changes in worker turnover before and after the change in EPA. Ideally we would like to compare the outcomes before and after the policy change for a group affected by the change (the treatment group) to a group not affected (the control group). The treatment group in our analysis consists of the oldest age group (45 - 64-year -olds). As discussed above we use 25 - 29-year-olds as the control. Our main analysis is based on comparing worker turnover for these two age groups. Other age groups are to a varying degree affected by the reform, as discussed above. These age groups, characterised by different treatment doses, are also studied. Moreover, outcomes for 45 - 64-year-old manual workers in engineering are contrasted to those of nonmanuals of the same age and in the same industry.

Based on our panel of individuals and firms, we estimate the following regression:

$$
\begin{aligned}
y_{i t}=\alpha_{0}+\alpha_{1} \text { Treated_Age_Group } & +\alpha_{2} \text { Post }_{t} \\
& +\alpha_{3}(\text { Treated_Age_Group } * \text { Post })_{i t}+x_{i t}^{\prime} \beta+z_{i t}^{\prime} \delta+\varepsilon_{i t}
\end{aligned}
$$

Our dependent variable in the analysis on hirings is an indicator variable equal to one if a worker is newly hired at time $t$ and zero otherwise. In regressions on separation behaviour, the dependent variable equals one if an individual is separating from a firm at time $t$ and zero otherwise. Treated_Age_Group is a dummy variable for belonging to the treated age group at time $t$, Post is a dummy variable for the postreform period, and Treated_Age_Group*Post is an interaction term between Treated_Age_Group and Post. The coefficient for the interaction term is the d-i-d estimate of the reform effect, reflecting the differential effect on the age group affected by the change in the EPA relative to the (basically) unaffected youngest age group. The d-i-d estimator allows for both group-specific and time-specific effects.

Furthermore, $x_{i t}$ is a vector of time-varying individual characteristics, and $z_{i t}$ is a vector of time-varying firm characteristics. The individual and firm controls are dummies for the individual's education, the log of the number of employees, the 
capital-labour ratio, the value added per employee, the share of females and the share of employees with post-secondary education. The additional explanatory variables control for the observable differences between the two groups, which means that they account for the possibility that characteristics are systematically different before and after the policy change (compositional bias). All of the estimations include year, subindustry and regional fixed effects in which, for instance, the year fixed-effects control for common shocks to the business cycle.

A crucial assumption behind the $\mathrm{d}-\mathrm{i}-\mathrm{d}$ estimator is the parallel trend assumption. One method to check for parallel trends is to use placebo periods. By using data on prior periods, the d-i-d regressions can be re-estimated by studying the years during which there were no policy changes. If the placebo estimators are statistically significant, then there is a risk that the estimated d-i-d coefficients are biased. As a check for robustness, we estimate a large number of different placebo regressions. The nature of the reforms during the notice periods makes it possible to apply placebo regressions in two different ways. First, we estimate placebo regressions based on prior non-reform years. Second, the different timing of the reforms in different industries allows us to estimate placebo regressions on combinations of industries and collective agreements that have not undertaken any reforms.

The manner in which the standard errors should be clustered to account for autocorrelation and within-firm or within-individual correlations is not obvious (see Bertrand et al., 2004). Several alternatives are possible with our data on individuals and firms. These options include clustering at the worker, age group or firm levels. We have chosen to use the most conservative alternative, which is clustering at the firm level (producing the highest standard errors). ${ }^{16}$

Another issue related to the $d-i-d$ approach is that the composition of the groups of treated and untreated individuals should be stable over time. The reform of advance notice can influence worker turnover by changing the behaviour of the existing workforce (incentive effect) and/or by changing the composition of workers (compositional effect). The risk of a composition bias is mitigated in our case because we use individual data in which we can follow workers before and after the reforms.

One potential concern with the estimation of the regression equation relates to omitted variables bias. To account for the impact of other individual and firm characteristics that might influence results, we estimate specifications with a large number of alternative control variables. These variables include controls for the share 
of 45 - 64-year-olds at the firm level and the share of manual workers. Both of these variables are used to account for the possibility that the impact of the change in notice period is related to the composition of the firms' work force.

Year dummies are included in the regressions as a control for business cycle effects that are common to all employees. This measure may be too crude if macroeconomic conditions have differential effects across age groups. We therefore estimate alternative regressions in which we add age-specific unemployment to the specifications.

We also estimate more flexible empirical specifications, allowing the treated age group to be on a different trend than other age groups. ${ }^{17}$ When allowing for different trends, we include an interaction term between the treated age group and a time trend.

Finally, reverse causality is a potential problem in studies on the effects of employment protection. One obvious possibility is that both legislative changes in the EPA and their implementation in collective agreements are triggered by deteriorating labour market conditions for older workers. Regarding rules for advance notice, with the exception of the Engineering Agreement for manuals, our collective agreements are constructed in such a way that legislative changes have no effect during the agreement period, which is typically $2-3$ years. Moreover, because deviations from legislation regarding notice periods are negotiated mainly at the industry level and only rarely at the firm level, decisions by firms regarding hirings and separations can be assumed to be exogenous. Another advantage with our data is that treatment is based on age, an individual characteristic that is exogenous. ${ }^{18}$

\section{Results}

In the first part of this section we present our basic parameter estimates. The second part deals with robustness checks.

Basic Results The results for hirings and separations in engineering are presented in Tables 4 (manuals) and 5 (non-manuals), and the corresponding results for retail are shown in Table 6 (manuals). Each table contains three panels with regressions for different lengths of the post-reform periods to examine whether the effects of the reforms differ in the short and the longer term. All of the regressions are based on the 
same length of the pre-reform period, namely three years. Panel a) considers a postreform period of one year, panel b) two years and panel c) three years. In each panel, more controls are successively added to the regressions - individual- and firmspecific controls and firm fixed-effects. The first four columns in each table display the results for hirings, and columns $5-8$ relate to separations.

Columns 1 and 5 report the regressions for the simplest specification, with dummies for the variables for age 45 - 64, the post-reform period and the reform effect (the interaction between treatment group and post-reform period) plus (nonreported) dummies for region and year. In columns 2 and 6, individual and firmspecific controls, commonly included in similar analyses and that could impinge on turnover, are added. Columns 3 and 7 restrict the sample to a balanced firm panel, and the final specifications (4 and 8) introduce firm fixed-effects. The latter specifications control for unobserved, firm-specific and time-invariant factors that contribute to turnover, such as working environment. Of main interest is the coefficient for the reform effect and its sensitivity to different specifications. The reform effect for $45-$ 64-year-olds is based on 25 - 29-year-olds as the control in Tables 4 - 6, but later we will examine the sensitivity of the results to the use of other age groups as controls.

\section{- Table 4 about here -}

As expected, the dummy for age 45 - 64 is negative in all of the regressions in Table 4, reflecting less turnover among older workers. The estimated coefficient for the reform variable is 0.043 in the first column of panel a). Taken at face value, this estimate means that the 1997 reform implied a short-run increase in the hiring rate of 4.3 percentage points among workers aged 45 - 64 in relation to the rate among 25 29-year-olds. As more controls are added, the estimate does not change (column 2). Columns 3 and 4 show estimates on a balanced firm panel. Based on this smaller subsample of individuals and firms, the reform effect is not very different (0.049).

In the longer term, the effect on hirings wanes out and becomes insignificant, but is still positive, as seen in panels b) and c) in which the post-reform periods are two and three years, respectively.

On the whole, not much seems to happen to separations for manual workers in engineering. Most of the estimates are negative, but in all cases of small magnitude. Table 4 thus indicates that there was an initial but short-lived response in the form of more hirings without any change in separations. 
What about non-manual workers in engineering? Here, the regressions in panel a) of Table 5 indicate an initial effect of the 2001 reform on hirings of about 0.040. In contrast to the regressions for manuals, the effect survives as the post-reform periods are extended. As for separations, the initial estimate is 0.018 (in column 5), and this increase is sustained as the evaluation period increases. Thus, the net gain in employment for older workers was initially smaller for non-manuals than for manuals.

- Table 5 about here -

The pattern of hirings in retail is shown in Table 6. After an initial response of approximately 0.020, the effect of the reform in 2001 is strengthened over time, up to about 0.050 in panel c). However, the contemporaneous effect on separations is somewhat larger throughout, which means that there is a marked increase in the turnover but hardly any net increase in the employment among manuals in retail. As in the regressions for non-manuals in engineering, we find an increase in separations already in the short run, which may be surprising given the design of the reform. An explanation may be that turnover is larger for workers in these agreements than among manuals in engineering (see Table A.3).

- Table 6 about here -

So far we have looked at the expected firing cost of the individual worker without taking into account intra-firm decision making. It may be the case that it also matters where the worker is ranked in the distribution of firing costs of all workers in the firm. This issue relates mainly to separations, since all newly hired workers after the reform were subject to the same firing cost. Exploring the possibility that the ranking of firing costs matters, we first calculated the median notice period in each firm. Separate medians were calculated for workers covered by the collective agreements for manuals and non-manuals. Then we divided the sample according to whether the notice period of the individual worker is below or above the relevant median in the firm, at the time of separation. ${ }^{19}$ Table 7 presents regressions for separations, splitting the sample into workers with "short" and "long” notice period in relation to the firm median. The specifications are the same as those in column 6 in Tables $4-6$, which is our preferred specification. ${ }^{20}$ For brevity, only the reform effects are displayed. The main message in Table 7 is that reform effects are more pronounced among workers 
with a short relative notice period than among those with a longer one. The effects tend to increase over time. Thus the ranking within the distribution of firing costs matters. An exception is manuals in engineering, but for this group no overall effect on separations could be established in Table 4 .

- Table 7 about here -

Sensitivity Analyses and Tests for Heterogeneous Effects To check the robustness and heterogeneity of the estimates in Tables $4-6$, several additional regressions were run. One concern with the estimates is that 25 - 29-year-olds are a group of workers that are potentially different from 45 - 64-year-olds, in terms of unobserved worker and job characteristics, despite being the group least affected by the reforms (apart from 18-24-year-olds) and thus not suitable as a control. Another concern is that those in the age group $60-64$ were affected by the stricter rules for eligibility of disability insurance in 1997 and that a reform in the same year made it easier for firms to deviate from seniority rules when dismissing workers older than 57.5 years due to lack of work (as discussed previously). In addition, using a treatment group that is close to retirement age may be problematic. For these reasons, we experimented with using various age groups as control groups in response to the first concern and restricting the treatment group to the age interval 45 - 59 as a way to handle the second and third concerns.

The robustness checks for manuals in engineering are displayed in Table 8. We contrast the results to a benchmark in the form of the preferred specifications in column 2 of Table 4 for hirings and column 6 for separations.

- Table 8 about here -

The estimated reform effects are heterogeneous with regard to age of the control group; they decrease in size and statistical significance as successively older control groups are used, which is as expected because the treatment dose gets closer to the one administered to the 45 - 64-year-olds. When the control group is restricted to 40 - 44-year-olds (the closest age group), no significant effect on hirings is found for the first year following the reform while the estimates for longer periods show negative effects. Changing the treatment group to 45 - 59-year-olds imply results that 
are basically unchanged. When 45 - 64-year-old non-manuals in the same industry are used as controls the estimated effects are small, but insignificant in most cases. However, the net effect on employment is consistently positive since the coefficients for hirings retain a positive sign while those for separations are all negative.

Another concern with the benchmark estimates derives from the fact that the EPA reform in 1997 affected all of the firms not bound by a collective agreement, regardless of industry. Hence, the effects of the collectively negotiated reforms in 2001 may be underestimated because some firms in the industry had already been treated in 1997. This condition is of no concern for manuals in engineering for which the EPA reform was implemented immediately, but the results for the other groups under consideration could be affected. We have no direct information as to whether a firm is covered by collective agreement, but non-coverage is more prevalent among small firms and virtually absent in the largest firms. If this aspect is important, we expect to find smaller effects in the smallest firms following the 2001 reforms. The results could differ depending on firm size for other reasons as well, but in the opposite direction. To the extent that it is more costly for small firms to adapt to employment protection regulation due to, for example, its fixed costs being spread over fewer employees, the estimated effects of the reforms may be larger in these firms. Thus, we checked for robustness in this respect by running regressions for two subgroups of firm sizes, namely those with up to 49 employees and those with 50 or more employees. For hirings, the results suggest a negative response in small firms, while the results for large firms come close to the overall findings. Similarly, for separations, results are driven by firms with 50 or more employees

Another concern with the estimates in Tables $4-6$ relates to omitted variables bias. Year dummies are included in these regressions as a control for business cycle effects that are common to all employees. This measure may be too crude if macroeconomic conditions have differential effects across age groups. We have therefore experimented with adding age-specific unemployment to the specifications, which yields somewhat larger and significant longer-term effects mainly for hirings, but also for separations. The short-term effects are basically unchanged. Thus, for longer-run effects on hirings at least, the results are sensitive to the measurement of the business cycle. Our last exercise in Table 8 adds a trend interacted with a dummy for the treatment group, with little effect on the estimates for hirings but yielding marginally stronger effects on separations. ${ }^{21}$ 
Table 9 repeats the format of the robustness checks in Table 8 for nonmanuals in engineering. The pattern is similar: decreasing reform effects when older age groups are used as controls, less employment-enhancing effects on hirings in small firms. However, the results are more robust to the inclusion of age-specific unemployment. Including the interaction between the trend and the dummy for the treatment group reduces the short-term impact on hirings, in relation to the benchmark estimates. Regarding the results for manuals in retail that are displayed in Table 10, the most notable difference in relation to Tables $8-9$ is that the effects in small firms are closer in magnitude to those in large firms, but the former effects are in most cases larger. As mentioned above, one possible reason for this is higher costs for small firms to adapt to employment protection regulations, for instance due to fixed costs being spread over fewer employees. Another difference in results is that the regressions with the trend and age interactions show that the effects on hirings disappear in 2 out of 3 cases.

- Table 10 about here -

For a more profound check of the robustness of our findings, we performed placebo tests on the reforms. We applied the respective reforms to the "wrong" industries or worker categories and to years when no reforms were undertaken. Tables 11 and 12 report the placebo tests, based on our preferred specifications.

- Table 11 about here -

In Table 11, the "wrong” agreements are subjected to the reforms we have examined. Our approach here is to study workers that are not directly affected by the reforms in 1997. This can be done for manual workers in retail and non-manual workers in engineering since these two groups are directly affected four years later in 2001. This is the reason for using these two groups in the "wrong" industries estimations. Using the reform in 1997 as the placebo, the results for retail show negative estimates in most cases, while the results for non-manuals in engineering display a similar pattern to the results for manuals. In the latter case, a significantly positive short-run effect (0.034) is estimated for hirings. While this estimate is slightly 
smaller than the corresponding one for manuals (0.043), this finding raises some doubts about the findings in Tables $4-6$. One interpretation is that an unobserved industry shock, affecting manuals and non-manuals in a similar way, may be behind the pattern of estimates we observe.

However, another interpretation of this result is that there are spillover effects from the reform to non-manuals in the engineering industry. Such spillovers could exist if the two worker categories are interdependent in the production process or if equity concerns make it difficult for employers to treat the worker categories at the same workplace differently. For production technology to affect our estimates for non-manuals, the interdependency needs to be a specific kind, namely age-specific. For example, a decrease in the firing costs for 45 - 64-year-old manuals should increase the demand for non-manuals in the same age interval but not the demand for non-manuals in other age groups. We regard this kind of interdependency as less plausible but are not able to distinguish between the two potential explanations with the data at hand. ${ }^{22}$

Table 12 presents another set of placebo regressions. Here, estimations apply to "wrong” years, i.e., years preceding the actual reform. The overall impression is that mostly significantly negative reform effects are estimated, in about two-thirds of the cases. For both hirings and separations, only three cases out of 54 placebo regressions yield estimates that are positive and significant (at the 5 per cent level).

- Table 12 about here -

Studying the different collective agreements in more detail, we first note that the short-term reform effect on hirings is insignificant the year before the reform for manuals in engineering. A positive and significant reform effect is not obtained for hirings in any year prior to 1997, when the actual reform was implemented. For separations, a significantly positive effect is estimated in the year 1995.

For non-manuals in engineering, both short- and longer-run reform effects were obtained in Tables 5 and 9. Table 12 instead shows lack of significant short-run effects when using the year 2000, i.e. the year before the actual reform, as placebo reform year. All of the other years preceding 2001 are either significantly negative or statistically insignificant with the exception of the year 1999 in which we observe statistically significant reform effects for hirings that are in line with the ones obtained for the actual reform year. The corresponding placebo regressions on 
separations for non-manual employees in engineering show insignificant reform effects for the two years preceding the actual reform. In the placebo regressions for the periods three to five years prior to the reform, the coefficients are either negative and significant or insignificant. In sum, no positive and statistically significant reform effects for separations can be found for the placebo years, in contrast to the findings on the actual reform year presented in Tables 5 and 9.

Finally, the results for manual workers in retail, presented in Tables 6 and 10, showed a positive and significant reform effect on both hirings and separations. What about the corresponding placebo regressions? The bottom panel of Table 12 shows that the short-run reform effect is negative for the year preceding the actual reform, but significantly so only for hirings. For all of the other years, the placebo reform effects are either negative and significant or insignificant. ${ }^{23}$

The placebo exercises show that there are no systematic results to suggest that our findings in Tables $4-6$ can be dismissed as entirely spurious, but we remain cautious as to the interpretation of our results. We are inclined to place more emphasis on the placebo tests up to 1997 because the results for later years may be confounded by reforms of advance notice not observed by us in other industries in the economy. The overall picture conveyed by the placebo tests does not change, but it is notable that significantly positive effects are absent prior to $1997 .{ }^{24}$ The presence of negative estimates in the placebo regressions may be due to the labour market for old workers being relatively unfavourable before the actual reform, as shown by the development of unemployment by age in Figure 1.

\section{Conclusions}

In this paper, we have examined a reform of notice periods for employer-initiated separations in Sweden. The reform was aimed at encouraging the hiring of older workers by reducing the periods of notice for newly hired older workers from six months to one month. The new legislation implied minor or no changes in advance notices for younger workers and was initiated at different time in various industries through the implementation in collective agreements. These conditions provide ample opportunity for the identification of its effects. The analysis also provides insights into the implementation of employment protection legislation in collective agreements, which has received little attention in the literature previously, possibly due to the lack of data. 
Our findings indicate heterogeneous effects across collective agreements. Despite differences in terms of dynamics and size, a positive effect on hirings is found for all agreements. With the exception of manual workers in engineering, our results also show an increase in separations, indicating an increase in employment turnover. The risk of separation depends not only on the worker's expected firing cost, but also on where the worker is ranked in the distribution of firing costs of all workers in the firm. We find that reform effects are more pronounced among workers with a short relative notice period than among those with a longer one. Thus the ranking within the distribution of firing costs matters. To the best of our knowledge, this aspect of employment protection has not been explored in previous empirical research.

A salient feature of the results is that the estimated effects on hirings and separations increase with the treatment dose, i.e., the size of the reduction in months of the advance notices across different age groups.

We performed numerous robustness checks of our results. Most of these checks produced minor changes in the estimated coefficients. However, placebo tests with reforms in "wrong” years and in "wrong” agreements reveal significant effects in many cases, although with only a few cases with a positive sign as in the original regressions. It is notable that significantly positive effects are absent prior to 1997. The latter placebo tests are especially interesting since they are not confounded by reforms of advance notice not observed by us in other industries in the economy. It should also be emphasised that we do not capture general equilibrium effects in our analysis.

We feel confident in concluding that the reforms did not produce the perverse results established in some previous studies on employment protection reform targeted on vulnerable groups of workers, through the implementation of firing taxes. Our analysis suggests that the Swedish reforms did in no case cause separations to increase with little positive effect on hirings. This stands in contrast to the results obtained by Acemoglu and Angrist (2001) and Behaghel et al. (2008) for the United States and France, respectively. The more encouraging Swedish results may be explained by the design of the reforms, which granted extensive protection to workers remaining with the firm. However, as the number of older workers under the new rules accumulates over time, this particular feature of the reform is likely to diminish in importance. Our results may also reflect that voluntary separations among older workers were discouraged after the reform because job mobility would entail less employment protection for these workers. 


\section{References}

Acemoglu, Daron, and Joshua D. Angrist. 2001. "Consequences of Employment Protection? The Case of the Americans with Disabilities Act”. Journal of Political Economy 109 (5): 915-957.

Andersson, Pär, Stefan Fölster, and Per Skedinger. 2002. ”Omställning eller avstjälpning? Om utformningen av en omställningsförsäkring”. Arbetsmarknad \& Arbetsliv 8 (2): 131-143.

Angrist, Joshua D., and Jörn-Steffen Pischke. 2009. Mostly Harmless Econometrics: An Empiricist's Companion. Princeton, NJ: Princeton University Press.

Behaghel, Luc, Bruno Crépon, and Beatrice Sedillot. 2008. "The Perverse Effects of Partial Employment Protection Reform: The Case of French Older Workers “. Journal of Public Economics 92 (3-4): 696-721.

von Below, David, and Peter Skogman Thoursie. 2010. "Last-in First-out? Estimating the Effect of Seniority Rules in Sweden”. Labour Economics 17 (6): 987-997.

Bergström, Villy, and Epaminondas E. Panas. 1992. "How Robust is the Capital-Skill Complementarity Hypothesis?”. Review of Economics and Statistics 74 (3): 540546.

Bertrand, Marianne, and Sendhil Mullainathan. 1999. "Is There Discretion in Wage Setting? A Test Using Takeover Legislation”. Rand Journal of Economics 30 (3): 535-554.

Bertrand, Marianne, Esther Duflo, and Sendhil Mullainathan. 2004. "How Much Should We Trust Difference-in-Differences Estimates”. Quarterly Journal of Economics 119 (1): 249-275.

Cappellari, Lorenzo, Carlo Dell’Aringa, and Marco Leonardi. 2012. ”Temporary Employment, Job Flows and Productivity”. Economic Journal 122 (562): F188215.

Donald, Stephen G., and Kevin Lang. 2007. ”Inference with Difference-inDifferences and other Panel Data”. Review of Economics and Statistics 89 (2): 221-233.

Feldmann, Horst. 2003. “Labor Market Regulation and Labor Market Performance: Evidence Based on Surveys among Senior Business Executives”. Kyklos 56 (4): 509-540.

Fraisse, Henri, Francis Kramarz, and Corinne Prost. 2011. "Labor Disputes and Labor Flows”. Discussion Paper No. 5677. Bonn: IZA.

Heckman, James, and Carmen Pagés-Serra. 2000. “The Cost of Job Security Regulation: Evidence from Latin American Labor Markets”. Economía. 1 (1): 109-144.

Heyman, Fredrik, Fredrik Sjöholm, and Patrik Gustavsson Tingvall. 2007. "Is there Really a Foreign Ownership Wage Premium? Evidence from Matched EmployerEmployee Data”. Journal of International Economics 73 (2): 355-376.

Heyman, Fredrik, Fredrik Sjöholm, and Patrik Gustavsson Tingvall. 2011. "Multinationals, Cross-Border Acquisitions and Wage Dispersion”. Canadian Journal of Economics 44 (2): 627-650.

Heyman, Fredrik, and Per Skedinger. 2011. "Employment Protection Reform, Enforcement in Collective Agreements and Worker Flows”. Working Paper No 876. Stockholm: Research Institute of Industrial Economics.

Kugler, Adriana, and Giovanni Pica. 2008. "Effects of Employment Protection on Worker and Job Flows: Evidence from the 1990 Italian Reform”. Labour Economics 15 (1): 78-95.

Lunning, Lars, and Gudmund Toijer. 2006. Anställningsskydd. Kommentarer till anställningsskyddslagen. Ninth edition. Stockholm: Norstedts Juridik. 
Martins, Pedro S. 2009. "Dismissals for Cause: The Difference That Just Eight Paragraphs Can Make”. Journal of Labor Economics. 27 (2): 257-279.

Martinson, Sara. 2005. ”Omställningsavtal: mellan vilka, för vilka och på vilka sätt”. Rapport 2005:15. Uppsala: Institute for Labour Market Policy Evaluation.

National Mediation Office. 2009. Avtalsrörelsen och lönebildningen 2008. Medlingsinstitutets årsrapport. Stockholm: National Mediation Office.

Okudaira, Hiroko. 2008. "The Economic Costs of Court Decisions Concerning Dismissals in Japan: Identification by Judge Transfers”. Paper presented at the EALE conference in Amsterdam, 18-20 September 2008.

Regeringens proposition 1973:129. "Kungl. Maj:ts proposition med förslag till lag om anställningsskydd, m. m.”. Stockholm: Ministry of the Interior.

Regeringens proposition 1996/97:16. ”En arbetsrätt för ökad tillväxt”. Stockholm: Ministry of Labour.

Saint-Paul, Gilles. 2009. "Does the Welfare State Make Older Workers Unemployable?”. Discussion Paper No. 4440. Bonn: IZA.

Schivardi, Fabiano, and Roberto Torrini. 2008. "Identifying the Effects of Firing Restrictions through Size-Contingent Differences in Regulation”. Labour Economics 15 (3): 482-511.

Schnalzenberger, Mario, and Rudolf Winter-Ebmer. 2009. "Layoff Taxes and Employment of the Elderly”. Labour Economics 16 (6): 618-624.

Sedvallson, Kerstin. 1996. “Arbetsrätten: LO hotar dra in stöd till s. Missnöje med förslaget gör att 20 miljoner kronor från facket till partiet kan frysa inne”. Dagens Nyheter, September 7, 1996.

Skedinger, Per. 2010. Employment Protection Legislation. Evolution, Effects, Winners and Losers. Cheltenham, UK, and Northampton, MA: Edward Elgar.

Skedinger, Per. 2011. "Employment Consequences of Employment Protection Legislation”. Nordic Economic Policy Review 2 (1): 45-83. 
Figure 1. Unemployment rates, by age, 1990-2005

a) Age 16-34

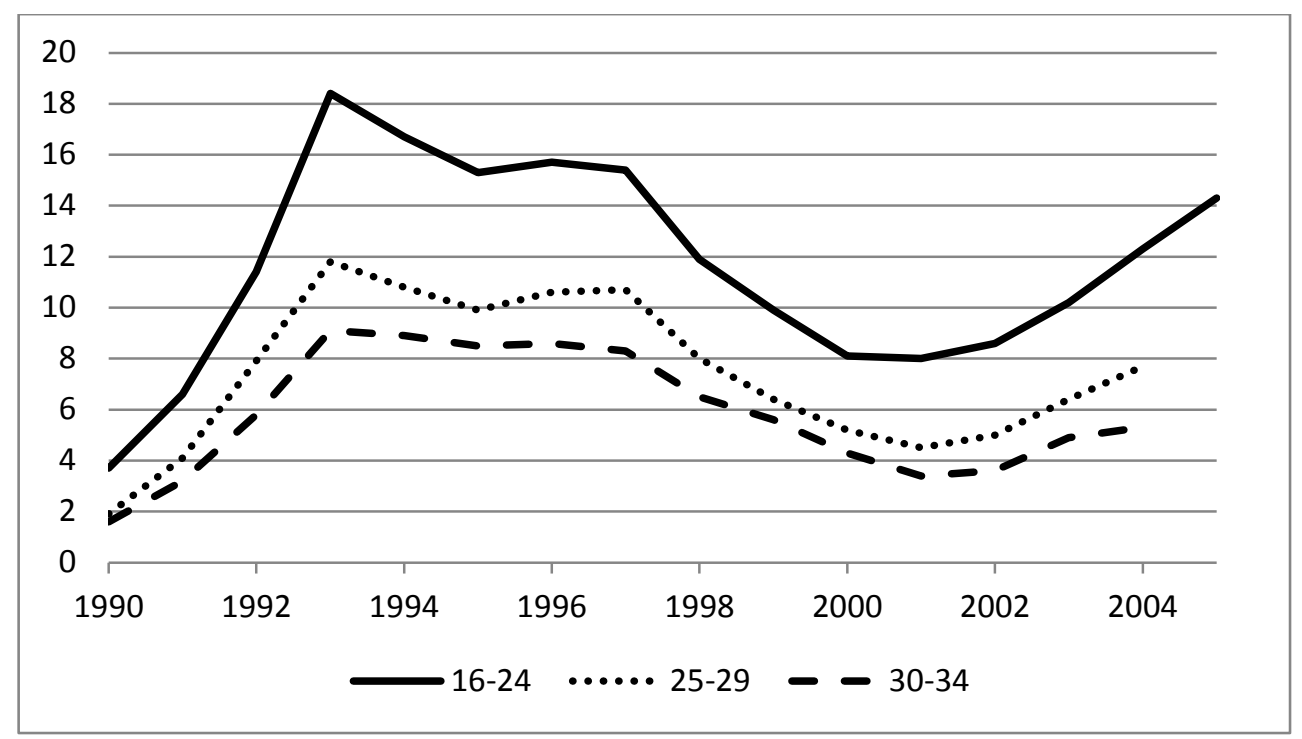

b) Age 50-64

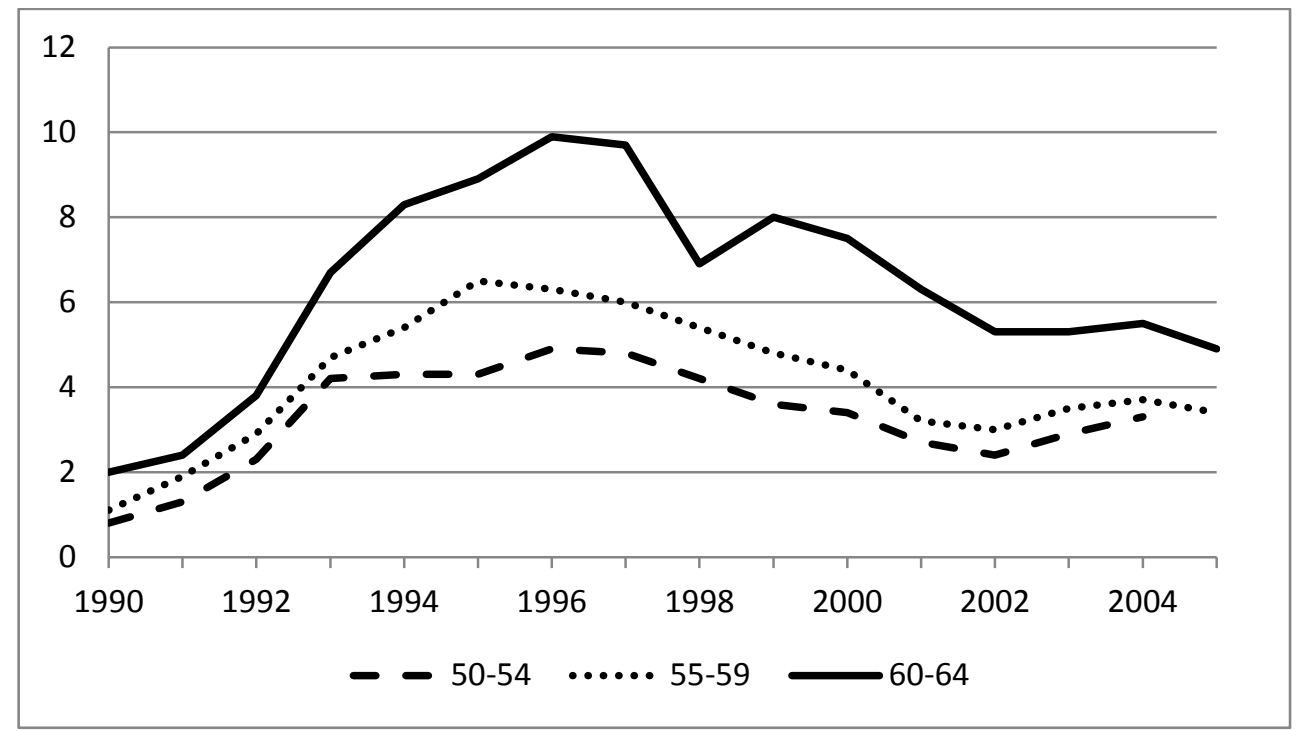

Source: Statistics Sweden.

Note: Data for 2005 are not available for age groups 25-29, 30-34 and 50-54. 
Figure 2. Hiring rates, by age

a) Manuals in engineering

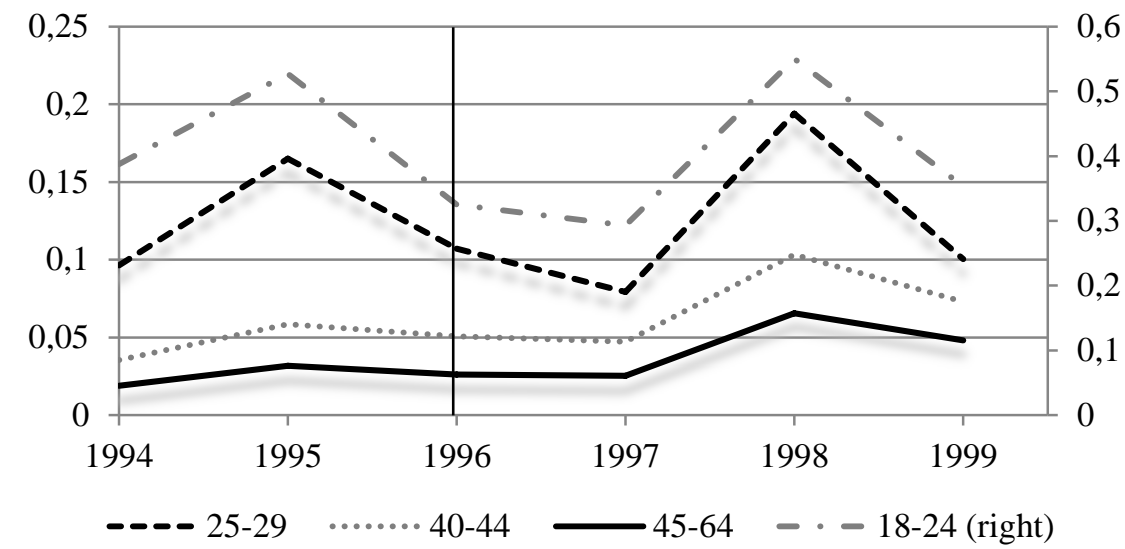

b) Non-manuals in engineering

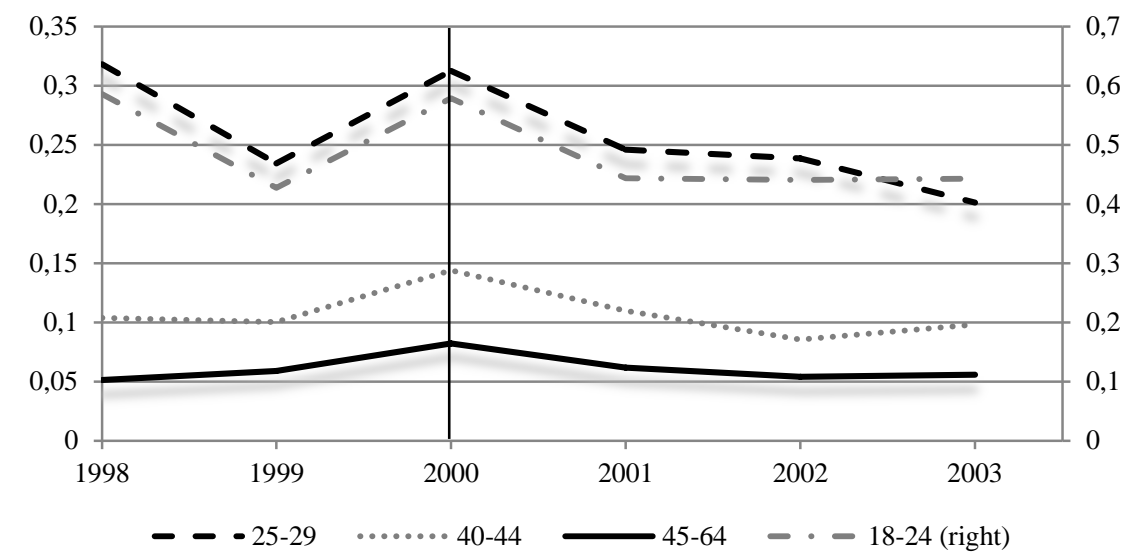

c) Manuals in retail

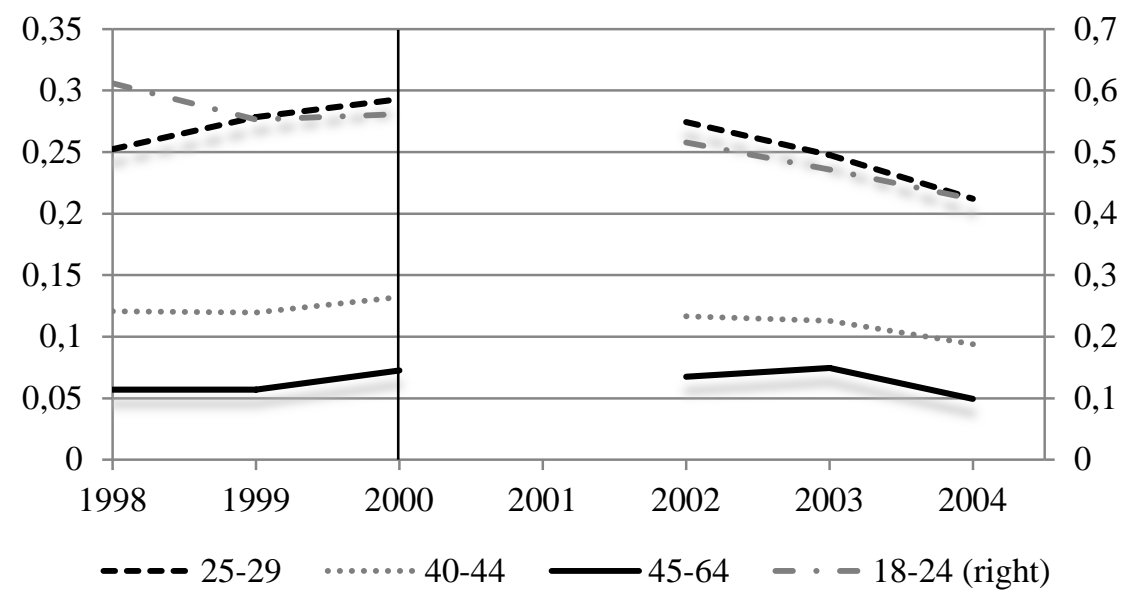

Notes: Vertical lines indicate the year before the reform. Right-hand side scale applies to 18 -24-yearolds. The age groups $25-29$ and $45-64$ are highlighted. 
Figure 3. Separation rates, by age

a) Manuals in engineering

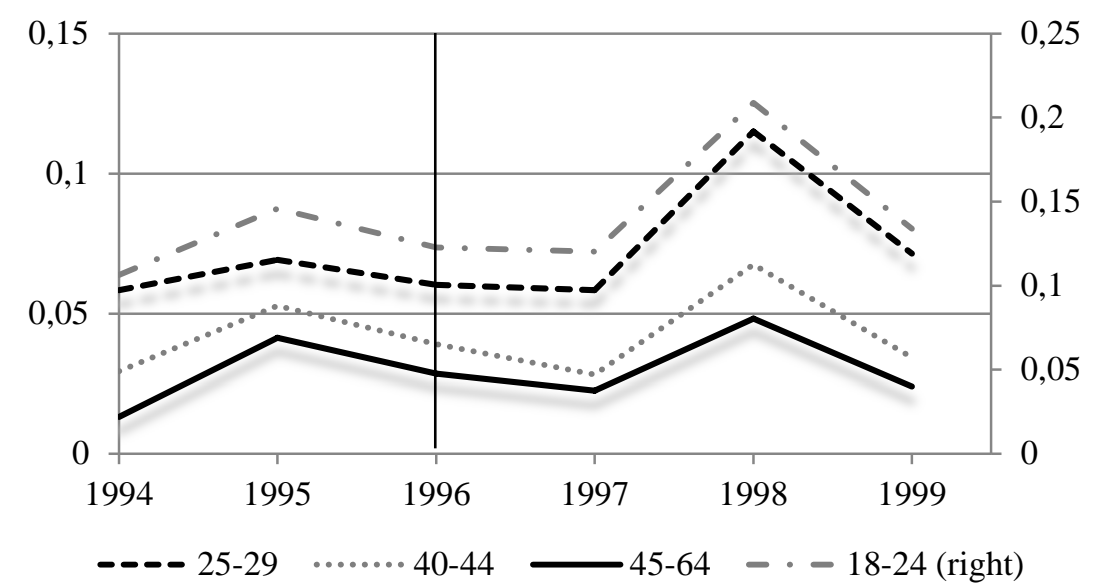

b) Non-manuals in engineering

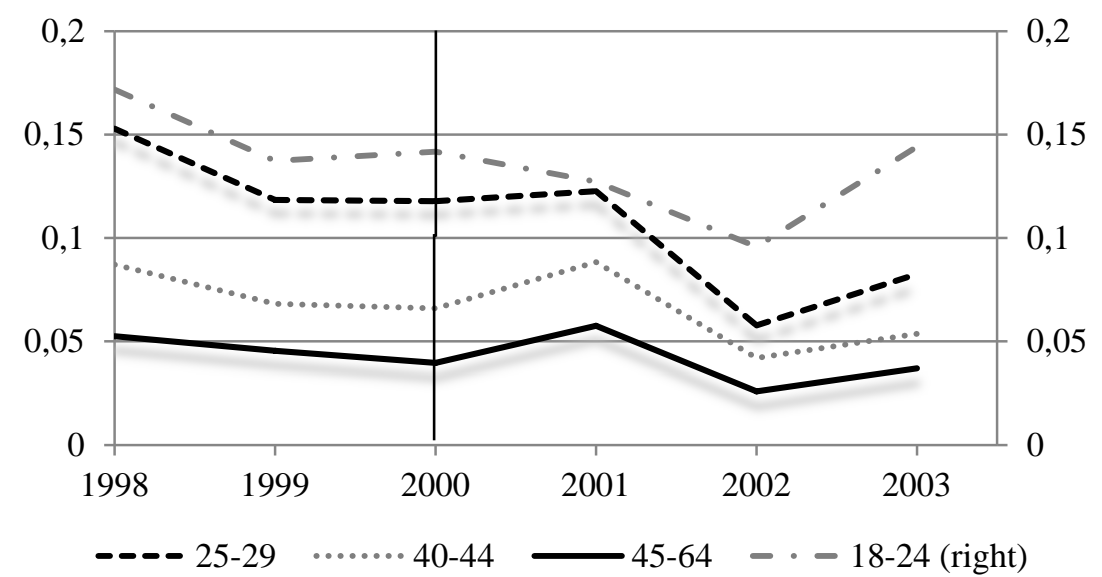

c) Manuals in retail

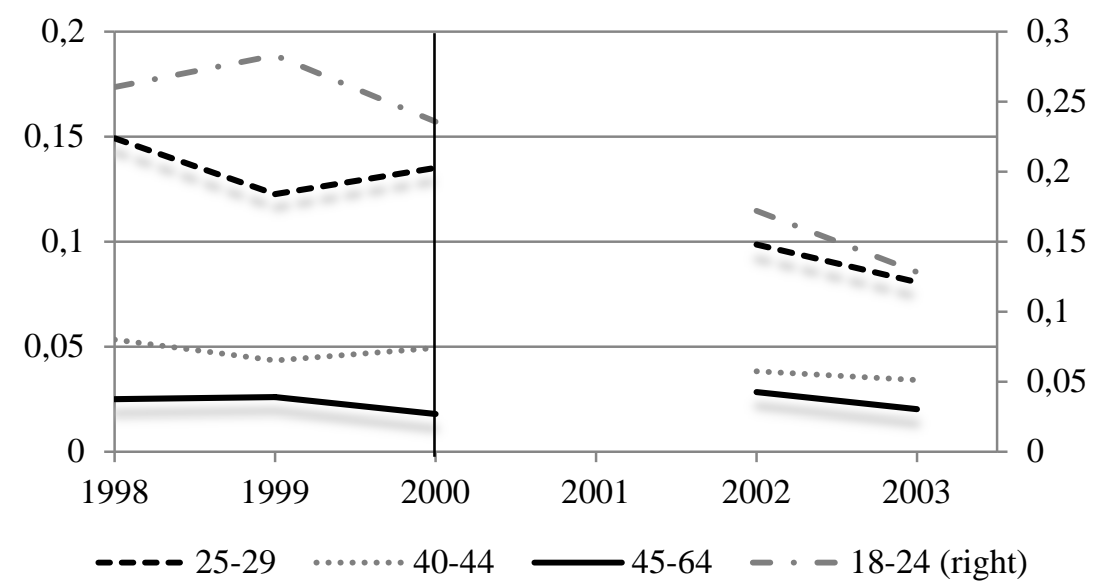

Note: See note to Figure 2. 
Figure 4. Worker flows among 45 - 64-year-olds in engineering

a) Hiring rates

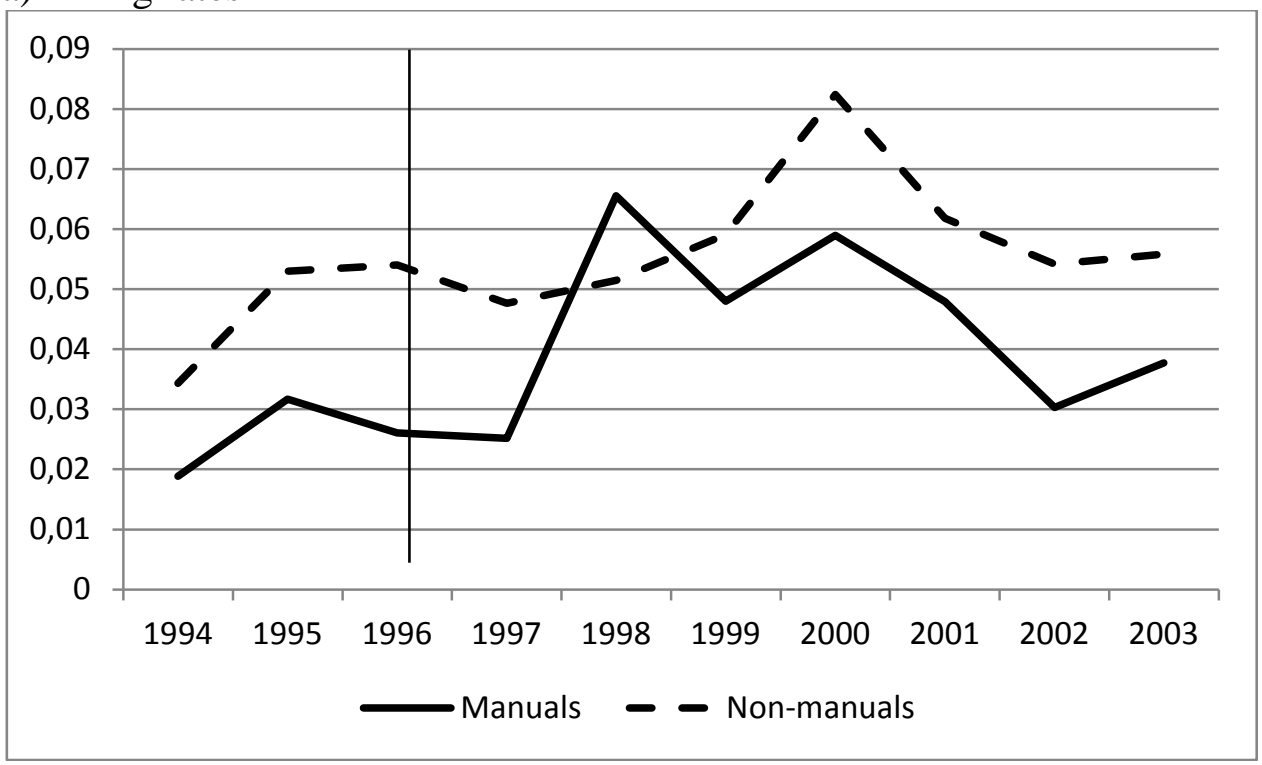

b) Separation rates

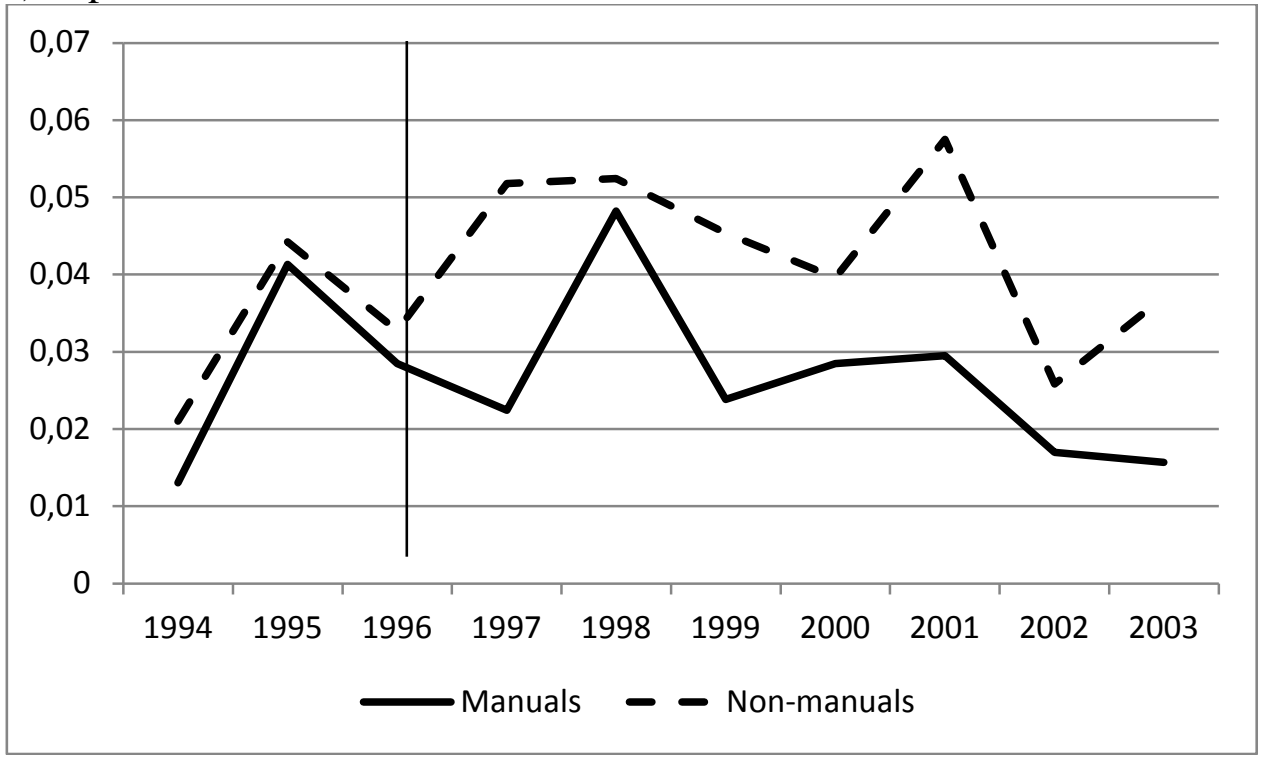


Table 1. Reform of terms of advance notice for employer-initiated separations in the Employment Protection Act, 1 January 1997

I. Rules before the reform, based on age of the employee:

1 month if age is 24 or younger

2 months if age is 25 to $29 *$

3 months if age is 30 to $34^{*}$

4 months if age is 35 to $39 *$

5 months if age is 40 to $44 *$

6 months if age is 45 or older*

* Applies to employees with a permanent contract who at the time of notice have been employed by the same firm for (i) the latest 6 consecutive months; or (ii) at least 12 months in total during the latest 2 years.

II. Rules after the reform**, based on tenure*** of the employee:

1 month if tenure is shorter than 2 years

2 months if tenure is at least 2 years but shorter than 4 years

3 months if tenure is at least 4 years but shorter than 6 years

4 months if tenure is at least 6 years but shorter than 8 years

5 months if tenure is at least 8 years but shorter than 10 years

6 months if tenure is at least 10 years

** Applies to employees with a permanent contract. The old rules continued to apply to employees employed by the same firm as before the reform.

*** Based on total length of employment by (i) the same firm; or (ii) firms belonging to the same combine; or (iii) firms having changed ownership through acquisitions and mergers. All types of employment count, including part-time and fixed-term employment.

Source: Lunning and Toijer (2006). 
Table 2. Reforms of terms of advance notice for employer-initiated separations in selected collective agreements, 1997-2001

\begin{tabular}{|l|l|l|l|l|l|l|}
\hline Industry & \multicolumn{3}{|c|}{ Manual Workers } & \multicolumn{2}{c|}{ Non-manual workers } \\
\cline { 2 - 7 } & $\begin{array}{l}\text { Pre-reform } \\
\text { rules }\end{array}$ & $\begin{array}{l}\text { Post-reform } \\
\text { rules }\end{array}$ & $\begin{array}{l}\text { Date of } \\
\text { reform }\end{array}$ & $\begin{array}{l}\text { Pre-reform } \\
\text { rules }\end{array}$ & $\begin{array}{l}\text { Post-reform } \\
\text { rules }\end{array}$ & $\begin{array}{l}\text { Date of } \\
\text { reform }\end{array}$ \\
\hline Engineering & $\begin{array}{l}\text { Old EPA, } \\
\text { age-based }\end{array}$ & $\begin{array}{l}\text { New EPA, } \\
\text { tenure-based }\end{array}$ & $\begin{array}{l}\text { January } \\
1,1997\end{array}$ & $\begin{array}{l}\text { CA-NM, } \\
\text { age/tenure- } \\
\text { based }\end{array}$ & $\begin{array}{l}\text { New EPA, } \\
\text { tenure-based }\end{array}$ & $\begin{array}{l}\text { February 1, } \\
2001\end{array}$ \\
\hline Construction & $\begin{array}{l}\text { CA-C, } \\
\text { age-based }\end{array}$ & $\begin{array}{l}\text { New EPA, } \\
\text { tenure-based } \\
\text { age/tenure- } \\
\text { based }\end{array}$ & 2000-01 & $\begin{array}{l}\text { New EPA, } \\
\text { tenure-based }\end{array}$ & $\begin{array}{l}\text { April 1, } \\
1998\end{array}$ \\
\hline Retail & $\begin{array}{l}\text { Old EPA, } \\
\text { age-based }\end{array}$ & $\begin{array}{l}\text { New EPA, } \\
\text { tenure-based }\end{array}$ & July 1, 2001 & Various & Various & Various \\
\hline
\end{tabular}

Notes: Old (New) EPA= rules in accordance with Employment Protection Act up to 1997 (after 1997); $\mathrm{CA}=$ rules specific to collective agreement for manual workers in construction (C) or for non-manual workers (NM) in general. Implementation for non-manual workers in retail varies depending on specific agreement. See Table A.1 in Appendix for further details.

Source: Collective agreements, except for manual workers in engineering, for which the source is circulars, entitled "Anställning och uppsägning”, distributed by the employer association Teknikföretagen to employers and kindly made available to us by Robert Tenselius at the association. 
Table 3. Expected discounted firing costs, before and after reform of advance notice, for workers hired at different ages. Monthly salaries

\begin{tabular}{|c|c|c|c|c|c|c|c|}
\hline \multirow{2}{*}{\multicolumn{2}{|c|}{ Agreement }} & \multicolumn{2}{|c|}{$\begin{array}{c}\delta=0.88 \\
a=1\end{array}$} & \multicolumn{2}{|c|}{$\begin{array}{c}\delta=\text { industry-specific } \\
\mathrm{a}=1\end{array}$} & \multicolumn{2}{|c|}{$\begin{array}{c}\delta=\text { industry-specific } \\
a=0.99\end{array}$} \\
\hline & & Age 20 & Age 45 & Age 20 & Age 45 & Age 20 & Age 45 \\
\hline $\begin{array}{l}\text { Engineering: } \\
\text { Manuals }\end{array}$ & $\begin{array}{l}\text { Pre-reform } \\
\text { Post-reform } \\
\text { Difference } \\
\text { Difference-in-difference }\end{array}$ & $\begin{array}{l}0.842 \\
1.499 \\
0.656\end{array}$ & $\begin{array}{l}3.428 \\
1.499 \\
-1.930 \\
586\end{array}$ & $\begin{array}{l}0.874 \\
1.514 \\
0.641\end{array}$ & $\begin{array}{l}3.847 \\
1.514 \\
-2.333 \\
74\end{array}$ & $\begin{array}{l}0.988 \\
1.629 \\
0.641\end{array}$ & $\begin{array}{l}3.996 \\
1.663 \\
-2.333 \\
974\end{array}$ \\
\hline $\begin{array}{l}\text { Engineering: } \\
\text { Non-manuals }\end{array}$ & $\begin{array}{l}\text { Pre-reform } \\
\text { Post-reform } \\
\text { Difference } \\
\text { Difference-in-difference }\end{array}$ & $\begin{array}{l}1.013 \\
1.499 \\
0.486\end{array}$ & $\begin{array}{l}3.798 \\
1.499 \\
-2.300 \\
786\end{array}$ & $\begin{array}{l}1.019 \\
1.514 \\
0.495\end{array}$ & $\begin{array}{l}4.125 \\
1.514 \\
-2.611 \\
06\end{array}$ & $\begin{array}{l}1.134 \\
1.629 \\
0.495\end{array}$ & $\begin{array}{l}4.273 \\
1.663 \\
-2.611 \\
06\end{array}$ \\
\hline $\begin{array}{l}\text { Retail: } \\
\text { Manuals }\end{array}$ & $\begin{array}{l}\text { Pre-reform } \\
\text { Post-reform } \\
\text { Difference } \\
\text { Difference-in-difference }\end{array}$ & $\begin{array}{l}0.842 \\
1.499 \\
0.656\end{array}$ & $\begin{array}{l}3.428 \\
1.499 \\
-1.930 \\
.586\end{array}$ & $\begin{array}{l}0.881 \\
1.473 \\
0.592\end{array}$ & $\begin{array}{l}4.176 \\
1.473 \\
-2.704 \\
96\end{array}$ & $\begin{array}{l}0.999 \\
1.591 \\
0.592\end{array}$ & $\begin{array}{l}4.330 \\
1.627 \\
-2.704 \\
96\end{array}$ \\
\hline $\begin{array}{l}\text { Construction: } \\
\text { Manuals }\end{array}$ & $\begin{array}{l}\text { Pre-reform } \\
\text { Post-reform } \\
\text { Difference } \\
\text { Difference-in-difference }\end{array}$ & $\begin{array}{l}0.796 \\
1.499 \\
0.702\end{array}$ & $\begin{array}{r}3.428 \\
1.499 \\
-1.930 \\
632\end{array}$ & $\begin{array}{l}0.866 \\
1.132 \\
0.267\end{array}$ & $\begin{array}{l}5.017 \\
1.132 \\
-3.885 \\
52\end{array}$ & $\begin{array}{l}0.985 \\
1.252 \\
0.267\end{array}$ & $\begin{array}{l}5.171 \\
1.286 \\
-3.885 \\
52\end{array}$ \\
\hline $\begin{array}{l}\text { Construction: } \\
\text { Non-manuals }\end{array}$ & $\begin{array}{l}\text { Pre-reform } \\
\text { Post-reform } \\
\text { Difference } \\
\text { Difference-in-difference }\end{array}$ & $\begin{array}{l}1.013 \\
1.499 \\
0.486\end{array}$ & $\begin{array}{r}3.798 \\
1.499 \\
-2.300 \\
786\end{array}$ & $\begin{array}{l}0.882 \\
1.132 \\
0.250\end{array}$ & $\begin{array}{l}5.016 \\
1.132 \\
-3.884 \\
34\end{array}$ & $\begin{array}{l}1.002 \\
1.252 \\
0.250\end{array}$ & $\begin{array}{l}5.170 \\
1.286 \\
-3.884 \\
34\end{array}$ \\
\hline
\end{tabular}

Notes: The calculations are based on the job security index constructed by Heckman and Pagés-Serra (2000, p. 138). The parameter $\delta$, which is the probability that the worker is not laid off during a given year, is 0.84 in engineering, 0.80 in retail and 0.56 in construction. The parameter $a$ denotes the probability that a dismissal is declared unjust by a court. Workers are assumed to have a minimum tenure of 1 year with the firm and maximum tenure of 20 years. For more details on the computations, see the index equation and related discussion in text. 
Table 4. Regressions for hirings and separations, manual workers in engineering, aged 45-64 and 25-29. Reform year: 1997.

a) 1994-97

\begin{tabular}{|c|c|c|c|c|c|c|c|c|}
\hline & (1) & (2) & (3) & (4) & (5) & (6) & (7) & (8) \\
\hline & \multicolumn{4}{|c|}{ Hirings } & \multicolumn{4}{|c|}{ Separations } \\
\hline Age 45-64 & $\begin{array}{c}-0.097^{* * *} \\
(11.73)\end{array}$ & $\begin{array}{c}-0.094^{* * *} \\
(11.39)\end{array}$ & $\begin{array}{c}-0.094^{* * *} \\
(10.70)\end{array}$ & $\begin{array}{c}-0.093^{* * *} \\
(10.58)\end{array}$ & $\begin{array}{c}-0.035^{* * *} \\
(9.43)\end{array}$ & $\begin{array}{c}-0.034^{* * *} \\
(9.92)\end{array}$ & $\begin{array}{c}-0.033^{* * *} \\
(9.16)\end{array}$ & $\begin{array}{l}-0.038^{* * *} \\
(10.82)\end{array}$ \\
\hline $\begin{array}{l}\text { Post-reform } \\
\text { period }\end{array}$ & $\begin{array}{c}-0.032^{* *} \\
(2.15)\end{array}$ & $\begin{array}{c}-0.065^{* \star *} \\
(3.78)\end{array}$ & $\begin{array}{c}-0.071^{* \star *} \\
(4.02)\end{array}$ & $\begin{array}{c}-0.049^{\star \star \star \star} \\
(3.84)\end{array}$ & $\begin{array}{c}-0.018 \\
(0.97)\end{array}$ & $\begin{array}{r}-0.012 \\
(0.88)\end{array}$ & $\begin{array}{l}-0.007 \\
(0.60)\end{array}$ & -0.010 \\
\hline Reform effect & $\begin{array}{c}0.043^{* * *} \\
(3.05)\end{array}$ & $\begin{array}{c}0.043^{* * *} \\
(3.20)\end{array}$ & $\begin{array}{c}0.049^{\star * *} \\
(3.56)\end{array}$ & $\begin{array}{c}0.049^{* \star *} \\
(3.76)\end{array}$ & $\begin{array}{l}-0.000 \\
(0.06)\end{array}$ & $\begin{array}{c}-0.000 \\
(0.01)\end{array}$ & $\begin{array}{l}0.001 \\
(0.17)\end{array}$ & $\begin{array}{l}0.002 \\
(0.34)\end{array}$ \\
\hline $\begin{array}{l}\text { Individual \& firm- } \\
\text { specific controls }\end{array}$ & $\mathrm{N}$ & $\mathrm{Y}$ & Y & $\mathrm{Y}$ & $\mathrm{N}$ & Y & $\mathrm{Y}$ & Y \\
\hline Firm panel & $\mathrm{N}$ & $\mathrm{N}$ & $\mathrm{Y}$ & $\mathrm{Y}$ & $\mathrm{N}$ & $\mathrm{N}$ & $\mathrm{Y}$ & $\mathrm{Y}$ \\
\hline Firm fixed effects & $\mathrm{N}$ & $\mathrm{N}$ & $\mathrm{N}$ & $\mathrm{Y}$ & $\mathrm{N}$ & $\mathrm{N}$ & $\mathrm{N}$ & $\mathrm{Y}$ \\
\hline No. observations & 129,778 & 129,778 & 119,167 & 119,167 & 126,438 & 126,438 & 107,676 & 107,676 \\
\hline No. firms & 360 & 360 & 134 & 134 & 427 & 427 & 124 & 124 \\
\hline R-squared (adj) & 0.038 & 0.045 & 0.046 & 0.062 & 0.017 & 0.033 & 0.038 & 0.065 \\
\hline
\end{tabular}

b) 1994-98

\begin{tabular}{|c|c|c|c|c|c|c|c|c|}
\hline & (1) & (2) & (3) & (4) & (5) & (6) & (7) & (8) \\
\hline & \multicolumn{4}{|c|}{ Hirings } & \multicolumn{4}{|c|}{ Separations } \\
\hline Age 45-64 & $\begin{array}{c}-0.097^{* * *} \\
(11.69)\end{array}$ & $\begin{array}{c}-0.092^{* * *} \\
(11.02)\end{array}$ & $\begin{array}{c}-0.097^{* * *} \\
(10.73)\end{array}$ & $\begin{array}{c}-0.095^{* * *} \\
(10.63)\end{array}$ & $\begin{array}{c}-0.035^{* * *} \\
(9.31)\end{array}$ & $\begin{array}{c}-0.033^{* * * *} \\
(7.87)\end{array}$ & $\begin{array}{c}-0.033^{* * *} \\
(7.29)\end{array}$ & $\begin{array}{c}-0.035^{* * *} \\
(7.38)\end{array}$ \\
\hline Post-reform & $0.054^{\star \star \star}$ & -0.002 & $-0.048^{\star *}$ & 0.012 & 0.026 & 0.047 & 0.063 & $-0.026^{*}$ \\
\hline period & (3.28) & $(0.15)$ & (2.41) & $(0.64)$ & (1.46) & $(1.36)$ & $(1.42)$ & $(1.73)$ \\
\hline Reform effect & 0.008 & 0.003 & 0.013 & 0.011 & -0.013 & $-0.013^{*}$ & -0.008 & -0.009 \\
\hline & $(0.56)$ & $(0.23)$ & $(0.84)$ & $(0.72)$ & (1.56) & (1.78) & $(0.99)$ & $(0.91)$ \\
\hline $\begin{array}{l}\text { Individual \& firm- } \\
\text { specific controls }\end{array}$ & $\mathrm{N}$ & $\mathrm{Y}$ & $\mathrm{Y}$ & $\mathrm{Y}$ & $\mathrm{N}$ & $\mathrm{Y}$ & $\mathrm{Y}$ & $\mathrm{Y}$ \\
\hline Firm panel & $\mathrm{N}$ & $\mathrm{N}$ & $\mathrm{Y}$ & $\mathrm{Y}$ & $\mathrm{N}$ & $\mathrm{N}$ & $\mathrm{Y}$ & $\mathrm{Y}$ \\
\hline Firm fixed effects & $\mathrm{N}$ & $\mathrm{N}$ & $\mathrm{N}$ & $\mathrm{Y}$ & $\mathrm{N}$ & $\mathrm{N}$ & $\mathrm{N}$ & $\mathrm{Y}$ \\
\hline No. observations & 170,706 & 170,706 & 139,677 & 139,677 & 169,578 & 169,578 & 131,216 & 131,216 \\
\hline No. firms & 453 & 453 & 109 & 109 & 525 & 525 & 109 & 109 \\
\hline R-squared (adj) & 0.041 & 0.052 & 0.054 & 0.066 & 0.033 & 0.064 & 0.081 & 0.124 \\
\hline
\end{tabular}

\section{c) 1994-99}

\begin{tabular}{|c|c|c|c|c|c|c|c|c|}
\hline & $(1)$ & $(2)$ & (3) & $(4)$ & $(5)$ & $(6)$ & $(7)$ & $(8)$ \\
\hline & \multicolumn{4}{|c|}{ Hirings } & \multicolumn{4}{|c|}{ Separations } \\
\hline Age 45-64 & $\begin{array}{c}-0.097^{* * *} \\
(11.42)\end{array}$ & $\begin{array}{c}-0.092^{* * *} \\
(10.82)\end{array}$ & $\begin{array}{c}-0.097^{* * *} \\
(10.44)\end{array}$ & $\begin{array}{c}-0.095^{* * *} \\
(10.50)\end{array}$ & $\begin{array}{c}-0.035^{* * *} \\
(9.16)\end{array}$ & $\begin{array}{c}-0.033^{* * *} \\
(8.14)\end{array}$ & $\begin{array}{c}-0.032^{* * *} \\
(6.97)\end{array}$ & $\begin{array}{c}-0.034^{* * *} \\
(7.22)\end{array}$ \\
\hline Post-reform & 0.005 & -0.007 & $-0.045^{* *}$ & -0.013 & 0.010 & 0.016 & $0.050^{*}$ & 0.032 \\
\hline period & $(0.32)$ & $(0.57)$ & $(2.28)$ & $(0.63)$ & $(1.01)$ & $(0.94)$ & $(1.65)$ & $(1.57)$ \\
\hline \multirow[t]{2}{*}{ Reform effect } & 0.020 & 0.013 & 0.022 & 0.021 & $-0.012^{*}$ & $-0.011^{*}$ & -0.007 & -0.011 \\
\hline & $(1.51)$ & (0.99) & $(1.50)$ & (1.37) & $(1.75)$ & $(1.78)$ & $(0.94)$ & (1.29) \\
\hline $\begin{array}{c}\text { Individual \& firm- } \\
\text { specific controls }\end{array}$ & $\mathrm{N}$ & $\mathrm{Y}$ & $\mathrm{Y}$ & $\mathrm{Y}$ & $\mathrm{N}$ & $\mathrm{Y}$ & $\mathrm{Y}$ & $\mathrm{Y}$ \\
\hline Firm panel & $\mathrm{N}$ & $\mathrm{N}$ & $\mathrm{Y}$ & $\mathrm{Y}$ & $\mathrm{N}$ & $\mathrm{N}$ & $\mathrm{Y}$ & $\mathrm{Y}$ \\
\hline Firm fixed effects & $\mathrm{N}$ & $\mathrm{N}$ & $\mathrm{N}$ & $\mathrm{Y}$ & $\mathrm{N}$ & $\mathrm{N}$ & $\mathrm{N}$ & $\mathrm{Y}$ \\
\hline No. observations & 208,302 & 208,302 & 157,828 & 157,828 & 208,063 & 208,063 & 147,042 & 147,042 \\
\hline No. firms & 550 & 550 & 92 & 92 & 623 & 623 & 85 & 85 \\
\hline R-squared (adj) & 0.036 & 0.049 & 0.053 & 0.062 & 0.026 & 0.047 & 0.062 & 0.096 \\
\hline
\end{tabular}

Note 1: Absolute t-statistics are robust to heteroskedasticity and clustered at the firm level.

Note 2: *** $\mathrm{p}<0.01, * * \mathrm{p}<0.05, * \mathrm{p}<0.1$

Note 3: All regressions include regional and year dummies and exclude observations of hirings and separations defined as outliers (see text). Individual and firm-specific controls consist of dummies for the individual's education, the log of the number of employees, the capital-labour ratio, value added per employee, the share of females, the share of employees with post-secondary education and six dummies for sub-industry. Absolute tvalues, adjusted for clustering at the firm level, within parentheses. 
Table 5. Regressions for hirings and separations, non-manual workers in engineering, aged 4564 and 25-29. Reform year: 2001.

a) $1998-2001$

\begin{tabular}{|c|c|c|c|c|c|c|c|c|}
\hline & $\overline{(1)}$ & (2) & (3) & (4) & (5) & (6) & (7) & (8) \\
\hline & \multicolumn{4}{|c|}{ Hirings } & \multicolumn{4}{|c|}{ Separations } \\
\hline Age 45-64 & $\begin{array}{c}-0.217^{* * *} \\
(15.80)\end{array}$ & $\begin{array}{c}-0.201^{* * *} \\
(14.21)\end{array}$ & $\begin{array}{c}-0.197^{* * *} \\
(12.19)\end{array}$ & $\begin{array}{c}-0.201^{* * *} \\
(11.81)\end{array}$ & $\begin{array}{c}-0.076^{* * *} \\
(11.41)\end{array}$ & $\begin{array}{l}-0.070^{* * * *} \\
(11.68)\end{array}$ & $\begin{array}{c}-0.071^{* * *} \\
(9.98)\end{array}$ & $\begin{array}{l}-0.074^{* * *} \\
(11.32)\end{array}$ \\
\hline $\begin{array}{l}\text { Post-reform } \\
\text { period }\end{array}$ & $\begin{array}{c}-0.039^{* *} \\
(2.34)\end{array}$ & $\begin{array}{c}-0.048^{\star * *} \\
(3.17)\end{array}$ & $\begin{array}{c}-0.035^{\star *} \\
(2.44)\end{array}$ & $\begin{array}{c}-0.075^{* * *} \\
(4.51)\end{array}$ & $\begin{array}{c}-0.003 \\
(0.18)\end{array}$ & $\begin{array}{c}-0.011 \\
(0.65)\end{array}$ & $\begin{array}{l}-0.013 \\
(0.56)\end{array}$ & $\begin{array}{l}0.019 \\
(0.96)\end{array}$ \\
\hline Reform effect & $\begin{array}{c}0.040^{* * *} \\
(2.85)\end{array}$ & $\begin{array}{c}0.045^{* * *} \\
(3.06)\end{array}$ & $\begin{array}{c}0.045^{* *} \\
(2.55)\end{array}$ & $\begin{array}{c}0.047^{* * \star} \\
(2.67)\end{array}$ & $\begin{array}{l}0.018^{*} \\
(1.67)\end{array}$ & $\begin{array}{c}0.025^{\star \star \star \star} \\
(2.87)\end{array}$ & $\begin{array}{c}0.029^{\star \star \star} \\
(2.84)\end{array}$ & $\begin{array}{l}0.021^{\star *} \\
(2.28)\end{array}$ \\
\hline $\begin{array}{l}\text { Individual \& firm- } \\
\text { specific controls }\end{array}$ & $\mathrm{N}$ & $\mathrm{Y}$ & $\mathrm{Y}$ & Y & $\mathrm{N}$ & $\mathrm{Y}$ & $\mathrm{Y}$ & $\mathrm{Y}$ \\
\hline Firm panel & $\mathrm{N}$ & $\mathrm{N}$ & $\mathrm{Y}$ & $\mathrm{Y}$ & $\mathrm{N}$ & $\mathrm{N}$ & $\mathrm{Y}$ & $\mathrm{Y}$ \\
\hline Firm fixed effects & $\mathrm{N}$ & $\mathrm{N}$ & $\mathrm{N}$ & $\mathrm{Y}$ & $\mathrm{N}$ & $\mathrm{N}$ & $\mathrm{N}$ & $\mathrm{Y}$ \\
\hline No. observations & 143,108 & 143,108 & 113,051 & 113,051 & 140,462 & 140,462 & 108,013 & 108,013 \\
\hline No. firms & 736 & 736 & 188 & 188 & 781 & 781 & 170 & 170 \\
\hline R-squared (adj) & 0.087 & 0.098 & 0.099 & 0.108 & 0.025 & 0.031 & 0.034 & 0.051 \\
\hline
\end{tabular}

b) 1998-2002

\begin{tabular}{|c|c|c|c|c|c|c|c|c|}
\hline & $(1)$ & $(2)$ & (3) & (4) & (5) & (6) & $(7)$ & $(8)$ \\
\hline & \multicolumn{4}{|c|}{ Hirings } & \multicolumn{4}{|c|}{ Separations } \\
\hline Age 45-64 & $\begin{array}{c}-0.218^{* * *} \\
(16.34)\end{array}$ & $\begin{array}{c}-0.201^{* * *} \\
(14.41)\end{array}$ & $\begin{array}{c}-0.200^{* * *} \\
(10.79)\end{array}$ & $\begin{array}{c}-0.203^{* * *} \\
(10.29)\end{array}$ & $\begin{array}{c}-0.077^{* * *} \\
(11.89)\end{array}$ & $\begin{array}{c}-0.070^{* * * *} \\
(12.40)\end{array}$ & $\begin{array}{c}-0.068^{* * *} \\
(12.06)\end{array}$ & $\begin{array}{l}-0.074^{* *+} \\
(11.78)\end{array}$ \\
\hline $\begin{array}{l}\text { Post-reform } \\
\text { period }\end{array}$ & $\begin{array}{c}-0.026^{*} \\
(1.74)\end{array}$ & $\begin{array}{c}-0.041^{\text {** }} \\
(2.21)\end{array}$ & $\begin{array}{c}-0.029^{* *} \\
(2.01)\end{array}$ & $\begin{array}{c}-0.051^{*} \\
(1.95)\end{array}$ & $\begin{array}{r}-0.014 \\
(0.88)\end{array}$ & $\begin{array}{c}-0.032^{*} \\
(1.69)\end{array}$ & $\begin{array}{c}-0.051^{\star \star \star \star} \\
(3.89)\end{array}$ & $\begin{array}{c}-0.009 \\
(0.40)\end{array}$ \\
\hline Reform effect & $\begin{array}{c}0.038^{\star \star \star *} \\
(2.83)\end{array}$ & $\begin{array}{c}0.043^{* * *} \\
(3.01)\end{array}$ & $\begin{array}{l}0.036^{*} \\
(1.87)\end{array}$ & $\begin{array}{l}0.036^{*} \\
(1.71)\end{array}$ & $\begin{array}{c}0.032^{\star \star \star *} \\
(4.60)\end{array}$ & $\begin{array}{c}0.037^{* \star * *} \\
(5.27)\end{array}$ & $\begin{array}{c}0.034^{* * *} \\
(5.07)\end{array}$ & $\begin{array}{c}0.032^{* * *} \\
(4.99)\end{array}$ \\
\hline $\begin{array}{l}\text { Individual \& firm- } \\
\text { specific controls }\end{array}$ & $\mathrm{N}$ & $\mathrm{Y}$ & $\mathrm{Y}$ & $\mathrm{Y}$ & $\mathrm{N}$ & $\mathrm{Y}$ & $\mathrm{Y}$ & $\mathrm{Y}$ \\
\hline Firm panel & $\mathrm{N}$ & $\mathrm{N}$ & $\mathrm{Y}$ & $\mathrm{Y}$ & $\mathrm{N}$ & $\mathrm{N}$ & $\mathrm{Y}$ & $\mathrm{Y}$ \\
\hline Firm fixed effects & $\mathrm{N}$ & $\mathrm{N}$ & $\mathrm{N}$ & $\mathrm{Y}$ & $\mathrm{N}$ & $\mathrm{N}$ & $\mathrm{N}$ & $\mathrm{Y}$ \\
\hline No. observations & 175,530 & 175,530 & 121,037 & 121,037 & 173,022 & 173,022 & 122,817 & 122,817 \\
\hline No. firms & 877 & 877 & 137 & 137 & 925 & 925 & 124 & 124 \\
\hline R-squared (adj) & 0.084 & 0.095 & 0.100 & 0.108 & 0.025 & 0.030 & 0.029 & 0.043 \\
\hline
\end{tabular}

c) $1998-2003$

\begin{tabular}{|c|c|c|c|c|c|c|c|c|}
\hline & (1) & $(2)$ & (3) & (4) & (5) & (6) & (7) & (8) \\
\hline & \multicolumn{4}{|c|}{ Hirings } & \multicolumn{4}{|c|}{ Separations } \\
\hline Age 45-64 & $\begin{array}{c}-0.218^{* * *} \\
(15.92)\end{array}$ & $\begin{array}{c}-0.201^{* * *} \\
(14.59)\end{array}$ & $\begin{array}{c}-0.194^{* * *} \\
(11.10)\end{array}$ & $\begin{array}{c}-0.196^{* * *} \\
(10.55)\end{array}$ & $\begin{array}{c}-0.077^{* * *} \\
(11.35)\end{array}$ & $\begin{array}{c}-0.071^{* * * *} \\
(11.96)\end{array}$ & $\begin{array}{c}-0.073^{* * *} \\
(10.68)\end{array}$ & $\begin{array}{c}-0.075^{* * *} \\
(10.93)\end{array}$ \\
\hline $\begin{array}{l}\text { Post-reform } \\
\text { period }\end{array}$ & $\begin{array}{c}-0.058^{\star * *} \\
(4.37)\end{array}$ & $\begin{array}{c}-0.050^{* * *} \\
(3.01)\end{array}$ & $\begin{array}{c}-0.059^{* * *} \\
(4.39)\end{array}$ & $\begin{array}{c}-0.057^{* *} \\
(2.21)\end{array}$ & $\begin{array}{c}-0.052^{\star \star \star *} \\
(2.58)\end{array}$ & $\begin{array}{c}-0.056^{* \star *} \\
(5.05)\end{array}$ & $\begin{array}{c}-0.043^{\star * *} \\
(2.70)\end{array}$ & $\begin{array}{c}-0.003 \\
(0.12)\end{array}$ \\
\hline Reform effect & $\begin{array}{c}0.049^{* * *} \\
(5.01)\end{array}$ & $\begin{array}{c}0.054^{* * *} \\
(5.07)\end{array}$ & $\begin{array}{c}0.049^{* \star \star} \\
(3.40)\end{array}$ & $\begin{array}{c}0.050^{* * *} \\
(3.25)\end{array}$ & $\begin{array}{c}0.034^{\star * *} \\
(4.08)\end{array}$ & $\begin{array}{c}0.038^{* * *} \\
(4.67)\end{array}$ & $\begin{array}{c}0.037^{* k *} \\
(4.37)\end{array}$ & $\begin{array}{c}0.033^{* * *} \\
(4.47)\end{array}$ \\
\hline $\begin{array}{l}\text { Individual \& firm- } \\
\text { specific controls }\end{array}$ & $\mathrm{N}$ & $\mathrm{Y}$ & $\mathrm{Y}$ & $\mathrm{Y}$ & $\mathrm{N}$ & $\mathrm{Y}$ & $\mathrm{Y}$ & $\mathrm{Y}$ \\
\hline Firm panel & $\mathrm{N}$ & $\mathrm{N}$ & $\mathrm{Y}$ & $\mathrm{Y}$ & $\mathrm{N}$ & $\mathrm{N}$ & $\mathrm{Y}$ & $\mathrm{Y}$ \\
\hline Firm fixed effects & $\mathrm{N}$ & $\mathrm{N}$ & $\mathrm{N}$ & $\mathrm{Y}$ & $\mathrm{N}$ & $\mathrm{N}$ & $\mathrm{N}$ & $\mathrm{Y}$ \\
\hline No. observations & 206,556 & 206,556 & 129,105 & 129,105 & 205,354 & 205,354 & 130,631 & 130,631 \\
\hline No. firms & 1,005 & 1,005 & 93 & 93 & 1,059 & 1,059 & 86 & 86 \\
\hline R-squared (adj) & 0.080 & 0.092 & 0.094 & 0.100 & 0.024 & 0.030 & 0.032 & 0.042 \\
\hline
\end{tabular}

Note: See notes to Table 4. 
Table 6. Regressions for hirings and separations, manual workers in retail, aged 45-64 and 2529. Reform year: 2001.

a) $1998-2002$

\begin{tabular}{|c|c|c|c|c|c|c|c|c|}
\hline & (1) & (2) & (3) & (4) & (5) & (6) & (7) & (8) \\
\hline & \multicolumn{4}{|c|}{ Hirings } & \multicolumn{4}{|c|}{ Separations } \\
\hline Age $45-64$ & $\begin{array}{c}-0.212^{* * *} \\
(22.63)\end{array}$ & $\begin{array}{c}-0.186^{* * *} \\
(21.40)\end{array}$ & $\begin{array}{c}-0.192^{* * *} \\
(20.56)\end{array}$ & $\begin{array}{c}-0.188^{* * *} \\
(19.07)\end{array}$ & $\begin{array}{c}-0.114^{* * *} \\
(20.47)\end{array}$ & $\begin{array}{c}-0.104^{* * * *} \\
(19.96)\end{array}$ & $\begin{array}{c}-0.109^{* * *} \\
(19.42)\end{array}$ & $\begin{array}{c}-0.108^{* * *} \\
(19.08)\end{array}$ \\
\hline $\begin{array}{l}\text { Post-reform } \\
\text { period }\end{array}$ & $\begin{array}{l}0.011 \\
(0.94)\end{array}$ & $\begin{array}{c}-0.014 \\
(1.14)\end{array}$ & $\begin{array}{c}-0.038^{\star \star \star *} \\
(2.70)\end{array}$ & $\begin{array}{c}-0.033^{*} \\
(2.08)\end{array}$ & $\begin{array}{c}-0.037^{\star \star *} \\
(6.16)\end{array}$ & $\begin{array}{c}-0.049^{\star \star \star} \\
(8.87)\end{array}$ & $\begin{array}{c}-0.058^{\star \star \star} \\
(7.87)\end{array}$ & $\begin{array}{c}-0.064^{* \star \star} \\
(7.11)\end{array}$ \\
\hline Reform effect & $\begin{array}{l}0.006 \\
(0.57)\end{array}$ & $\begin{array}{l}0.018^{*} \\
(1.78)\end{array}$ & $\begin{array}{l}0.024^{* \star} \\
(2.40)\end{array}$ & $\begin{array}{c}0.025^{* * *} \\
(2.64)\end{array}$ & $\begin{array}{c}0.036^{* \star *} \\
(5.55)\end{array}$ & $\begin{array}{c}0.047^{\star * *} \\
(8.17)\end{array}$ & $\begin{array}{c}0.051^{* * *} \\
(8.21)\end{array}$ & $\begin{array}{c}0.056^{\star \star \star *} \\
(9.10)\end{array}$ \\
\hline $\begin{array}{l}\text { Individual \& firm- } \\
\text { specific controls }\end{array}$ & $\mathrm{N}$ & Y & $\mathrm{Y}$ & Y & $\mathrm{N}$ & $\mathrm{Y}$ & $\mathrm{Y}$ & Y \\
\hline Firm panel & $\mathrm{N}$ & $\mathrm{N}$ & $\mathrm{Y}$ & $\mathrm{Y}$ & $\mathrm{N}$ & $\mathrm{N}$ & $\mathrm{Y}$ & $\mathrm{Y}$ \\
\hline Firm fixed effects & $\mathrm{N}$ & $\mathrm{N}$ & $\mathrm{N}$ & $\mathrm{Y}$ & $\mathrm{N}$ & $\mathrm{N}$ & $\mathrm{N}$ & $\mathrm{Y}$ \\
\hline No. observations & 89,035 & 89,035 & 69,274 & 69,274 & 83,268 & 83,268 & 62,985 & 62,985 \\
\hline No. firms & 930 & 930 & 158 & 158 & 968 & 968 & 141 & 141 \\
\hline R-squared (adj) & 0.086 & 0.095 & 0.103 & 0.114 & 0.048 & 0.053 & 0.062 & 0.069 \\
\hline
\end{tabular}

b) 1998-2003

\begin{tabular}{|c|c|c|c|c|c|c|c|c|}
\hline & $(1)$ & $(2)$ & (3) & (4) & (5) & (6) & $(7)$ & $(8)$ \\
\hline & \multicolumn{4}{|c|}{ Hirings } & \multicolumn{4}{|c|}{ Separations } \\
\hline Age 45-64 & $\begin{array}{c}-0.213^{* * *} \\
(22.74)\end{array}$ & $\begin{array}{c}-0.189^{* * *} \\
(21.46)\end{array}$ & $\begin{array}{c}-0.198^{* * *} \\
(19.59)\end{array}$ & $\begin{array}{c}-0.193^{* * *} \\
(18.60)\end{array}$ & $\begin{array}{c}-0.114^{* * *} \\
(20.19)\end{array}$ & $\begin{array}{c}-0.106^{* * * *} \\
(20.42)\end{array}$ & $\begin{array}{c}-0.111^{* * *} \\
(19.51)\end{array}$ & $\begin{array}{c}-0.110^{* * *} \\
(19.15)\end{array}$ \\
\hline $\begin{array}{l}\text { Post-reform } \\
\text { period }\end{array}$ & $\begin{array}{l}0.001 \\
(0.06)\end{array}$ & $\begin{array}{c}-0.020^{*} \\
(1.69)\end{array}$ & $\begin{array}{c}-0.043^{*} \\
(1.76)\end{array}$ & $\begin{array}{c}-0.025 \\
(1.32)\end{array}$ & $\begin{array}{c}-0.046^{* \star *} \\
(6.20)\end{array}$ & $\begin{array}{c}-0.062^{* \star * \star} \\
(71.97)\end{array}$ & $\begin{array}{c}-0.064^{\star \star \star \star *} \\
(7.24)\end{array}$ & $\begin{array}{c}-0.053^{* * x} \\
(6.19)\end{array}$ \\
\hline Reform effect & $\begin{array}{l}0.023^{\star \star} \\
(2.03)\end{array}$ & $\begin{array}{c}0.034^{* \star *} \\
(3.01)\end{array}$ & $\begin{array}{c}0.044^{\star \star \star \star} \\
(3.49)\end{array}$ & $\begin{array}{c}0.042^{\star * *} \\
(3.64)\end{array}$ & $\begin{array}{c}0.044^{* \star *} \\
(7.95)\end{array}$ & $\begin{array}{l}0.054^{* * *} \\
(10.12)\end{array}$ & $\begin{array}{l}0.057^{\star * \star} \\
(10.40)\end{array}$ & $\begin{array}{l}0.059^{* * *} \\
(10.74)\end{array}$ \\
\hline $\begin{array}{l}\text { Individual \& firm- } \\
\text { specific controls }\end{array}$ & $\mathrm{N}$ & $\mathrm{Y}$ & $\mathrm{Y}$ & $\mathrm{Y}$ & $\mathrm{N}$ & $\mathrm{Y}$ & $\mathrm{Y}$ & $\mathrm{Y}$ \\
\hline Firm panel & $\mathrm{N}$ & $\mathrm{N}$ & $\mathrm{Y}$ & $\mathrm{Y}$ & $\mathrm{N}$ & $\mathrm{N}$ & $\mathrm{Y}$ & $\mathrm{Y}$ \\
\hline Firm fixed effects & $\mathrm{N}$ & $\mathrm{N}$ & $\mathrm{N}$ & $\mathrm{Y}$ & $\mathrm{N}$ & $\mathrm{N}$ & $\mathrm{N}$ & $\mathrm{Y}$ \\
\hline No. observations & 115,602 & 115,602 & 81,468 & 81,468 & 106,310 & 106,310 & 75,034 & 75,034 \\
\hline No. firms & 1,106 & 1,106 & 81 & 81 & 1,111 & 1,111 & 86 & 86 \\
\hline R-squared (adj) & 0.080 & 0.088 & 0.095 & 0.108 & 0.045 & 0.050 & 0.059 & 0.063 \\
\hline
\end{tabular}

c) $1998-2004$

\begin{tabular}{|c|c|c|c|c|c|c|c|c|}
\hline & (1) & $(2)$ & (3) & (4) & (5) & (6) & (7) & $(8) S$ \\
\hline & \multicolumn{4}{|c|}{ Hirings } & \multicolumn{4}{|c|}{ Separations } \\
\hline Age 45-64 & $\begin{array}{c}-0.212^{* * *} \\
(22.56)\end{array}$ & $\begin{array}{c}-0.190^{* * *} \\
(21.64)\end{array}$ & $\begin{array}{c}-0.201^{* * *} \\
(19.64)\end{array}$ & $\begin{array}{l}-0.196^{* * *} \\
(18.82)\end{array}$ & $\begin{array}{c}-0.114^{* * *} \\
(20.22)\end{array}$ & $\begin{array}{c}-0.107^{* * * *} \\
(20.77)\end{array}$ & $\begin{array}{c}-0.111^{* * *} \\
(18.70)\end{array}$ & $\begin{array}{c}-0.111^{* * *} \\
(18.40)\end{array}$ \\
\hline $\begin{array}{l}\text { Post-reform } \\
\text { period }\end{array}$ & $\begin{array}{c}-0.005 \\
(0.46)\end{array}$ & $\begin{array}{c}-0.034^{* * *} \\
(21.41)\end{array}$ & $\begin{array}{c}-0.048^{* * *} \\
(3.45)\end{array}$ & $\begin{array}{c}-0.034^{* *} \\
(1.97)\end{array}$ & $\begin{array}{c}-0.049^{* \star *} \\
(6.85)\end{array}$ & $\begin{array}{c}-0.054^{\star \star *} \\
(11.23)\end{array}$ & $\begin{array}{c}-0.055^{* * *} \\
(11.00)\end{array}$ & $\begin{array}{c}-0.078^{* * *} \\
(7.88)\end{array}$ \\
\hline Reform effect & $\begin{array}{c}0.032^{* * *} \\
(3.14)\end{array}$ & $\begin{array}{c}0.044^{\star * *} \\
(4.29)\end{array}$ & $\begin{array}{c}0.058^{* \star \star} \\
(4.81)\end{array}$ & $\begin{array}{c}0.056^{* * *} \\
(5.02)\end{array}$ & $\begin{array}{c}0.048^{\star * *} \\
(9.29)\end{array}$ & $\begin{array}{l}0.057^{* * *} \\
(11.36)\end{array}$ & $\begin{array}{l}0.058^{* * *} \\
(11.31)\end{array}$ & $\begin{array}{l}0.060^{* * *} \\
(10.76)\end{array}$ \\
\hline $\begin{array}{l}\text { Individual \& firm- } \\
\text { specific controls }\end{array}$ & $\mathrm{N}$ & $\mathrm{Y}$ & $\mathrm{Y}$ & $\mathrm{Y}$ & $\mathrm{N}$ & $\mathrm{Y}$ & $\mathrm{Y}$ & $\mathrm{Y}$ \\
\hline Firm panel & $\mathrm{N}$ & $\mathrm{N}$ & $\mathrm{Y}$ & $\mathrm{Y}$ & $\mathrm{N}$ & $\mathrm{N}$ & $\mathrm{Y}$ & $\mathrm{Y}$ \\
\hline Firm fixed effects & $\mathrm{N}$ & $\mathrm{N}$ & $\mathrm{N}$ & $\mathrm{Y}$ & $\mathrm{N}$ & $\mathrm{N}$ & $\mathrm{N}$ & $\mathrm{Y}$ \\
\hline No. observations & 142,795 & 142,795 & 93,452 & 93,452 & 129,517 & 129,517 & 83,200 & 83,200 \\
\hline No. firms & 1,271 & 1,271 & 71 & 71 & 1,275 & 1,275 & 70 & 70 \\
\hline R-squared (adj) & 0.078 & 0.087 & 0.098 & 0.109 & 0.044 & 0.049 & 0.058 & 0.062 \\
\hline
\end{tabular}

Notes: The estimates of the reform effect are based on 2002 as the reform year, and excludes 2001. See also notes to Table 4. 
Table 7. The relationship between workers' relative notice period and separations. Reform effects.

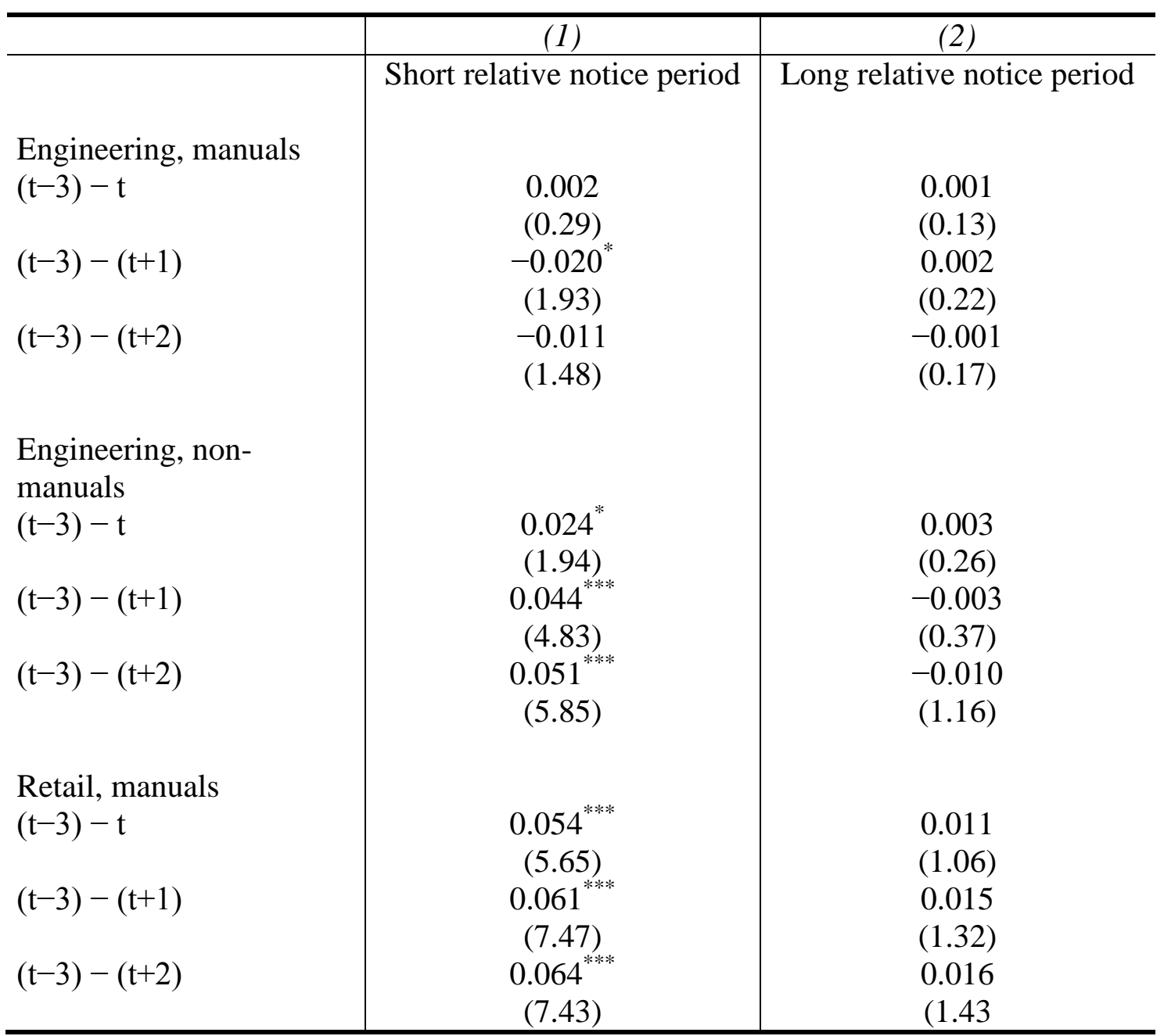

Notes: The samples are defined according to whether the notice period of the individual worker is below ("short") or above ("long") the relevant median in the firm, at the time of separation. Different medians apply depending on the collective agreement of the worker. See also notes to Table 4 . 
Table 8. Tests for robustness and heterogeneity, hirings and separations, manual workers in engineering. Reform effects

\begin{tabular}{|c|c|c|c|c|c|c|}
\hline & (1) & (2) & (3) & (4) & (5) & (6) \\
\hline & & Hirings & & & Separations & \\
\hline & 1994-97 & 1994-98 & 1994-99 & 1994-97 & 1994-98 & 1994-99 \\
\hline Benchmark (Table 4) & $\begin{array}{c}0.043^{* * *} \\
(3.20)\end{array}$ & $\begin{array}{l}0.003 \\
(0.23)\end{array}$ & $\begin{array}{l}0.013 \\
(0.99)\end{array}$ & $\begin{array}{c}-0.000 \\
(0.01)\end{array}$ & $\begin{array}{c}-0.013^{*} \\
(1.78)\end{array}$ & $\begin{array}{r}-0.011^{*} \\
(1.78)\end{array}$ \\
\hline \multicolumn{7}{|l|}{ Subgroups } \\
\hline \multicolumn{7}{|l|}{ Age: } \\
\hline $18-24 / 45-64$ & $\begin{array}{c}0.128^{* * *} \\
(4.27)\end{array}$ & $\begin{array}{l}0.017 \\
(0.50)\end{array}$ & $\begin{array}{l}0.037 \\
(1.25)\end{array}$ & $\begin{array}{l}0.006 \\
(0.75)\end{array}$ & $\begin{array}{c}-0.021 \\
(1.48)\end{array}$ & $\begin{array}{c}-0.017 \\
(1.47)\end{array}$ \\
\hline $30-34$ / 45-64 & $\begin{array}{c}0.029^{* * *} \\
(3.36)\end{array}$ & $\begin{array}{l}0.009 \\
(1.23)\end{array}$ & $\begin{array}{c}0.015^{* *} \\
(2.26)\end{array}$ & $\begin{array}{c}-0.002 \\
(0.37)\end{array}$ & $\begin{array}{c}-0.006 \\
(0.78)\end{array}$ & $\begin{array}{c}-0.007 \\
(1.09)\end{array}$ \\
\hline $35-39$ / 45-64 & $\begin{array}{c}0.014^{* *} \\
(2.11)\end{array}$ & $\begin{array}{c}-0.001 \\
(0.22)\end{array}$ & $\begin{array}{l}0.002 \\
(0.44)\end{array}$ & $\begin{array}{l}0.004 \\
(0.95)\end{array}$ & $\begin{array}{l}-0.002 \\
(0.40)\end{array}$ & $\begin{array}{c}-0.005 \\
(0.96)\end{array}$ \\
\hline $40-44$ / 45-64 & $\begin{array}{l}0.001 \\
(0.17)\end{array}$ & $\begin{array}{c}-0.009^{* *} \\
(2.11)\end{array}$ & $\begin{array}{c}-0.008^{* *} \\
(2.04)\end{array}$ & $\begin{array}{c}0.007^{* *} \\
(2.57)\end{array}$ & $\begin{array}{l}0.000 \\
(0.02)\end{array}$ & $\begin{array}{l}0.001 \\
(0.29)\end{array}$ \\
\hline $25-29 / 45-59$ & $\begin{array}{c}0.043^{* * *} \\
(3.17)\end{array}$ & $\begin{array}{l}0.004 \\
(0.28)\end{array}$ & $\begin{array}{l}0.014 \\
(1.06)\end{array}$ & $\begin{array}{c}-0.000 \\
(0.01)\end{array}$ & $\begin{array}{c}-0.014^{*} \\
(1.80)\end{array}$ & $\begin{array}{c}-0.011^{*} \\
(1.77)\end{array}$ \\
\hline $45-64^{\mathrm{a}} / 45-64$ & $\begin{array}{l}0.002 \\
(0.21)\end{array}$ & $\begin{array}{l}0.018 \\
(1.46)\end{array}$ & $\begin{array}{l}0.014 \\
(1.28)\end{array}$ & $\begin{array}{c}-0.022^{* *} \\
(2.44)\end{array}$ & $\begin{array}{c}-0.006 \\
(0.48)\end{array}$ & $\begin{array}{c}-0.008 \\
(0.93)\end{array}$ \\
\hline Firm size: & & & & & & \\
\hline $1-49$ & $\begin{array}{c}-0.021 \\
(0.55)\end{array}$ & $\begin{array}{c}-0.069^{* *} \\
(2.12)\end{array}$ & $\begin{array}{c}-0.061^{* *} \\
(1.98)\end{array}$ & $\begin{array}{c}-0.005 \\
(0.18)\end{array}$ & $\begin{array}{l}0.007 \\
(0.30)\end{array}$ & $\begin{array}{l}0.004 \\
(0.15)\end{array}$ \\
\hline$\geq 50$ & $\begin{array}{c}0.044^{* * *} \\
(3.24)\end{array}$ & $\begin{array}{l}0.004 \\
(0.25)\end{array}$ & $\begin{array}{l}0.013 \\
(1.01)\end{array}$ & $\begin{array}{l}0.000 \\
(0.05)\end{array}$ & $\begin{array}{c}-0.014^{*} \\
(1.78)\end{array}$ & $\begin{array}{c}-0.011^{*} \\
(1.76)\end{array}$ \\
\hline $\begin{array}{c}\text { Additional variables } \\
\text { Age-specific } \\
\text { unemployment }\end{array}$ & $\begin{array}{c}0.047^{* * *} \\
(3.38)\end{array}$ & $\begin{array}{c}0.046^{* * *} \\
(3.15)\end{array}$ & $\begin{array}{l}0.030^{*} \\
(1.95)\end{array}$ & $\begin{array}{c}-0.005 \\
(1.01)\end{array}$ & $\begin{array}{c}-0.020^{* * *} \\
(2.62)\end{array}$ & $\begin{array}{c}-0.020^{* *} \\
(2.49)\end{array}$ \\
\hline Trend x Age 45-64 & $\begin{array}{c}0.038^{* * *} \\
(2.73)\end{array}$ & $\begin{array}{c}-0.017 \\
(0.93)\end{array}$ & $\begin{array}{l}0.002 \\
(0.15)\end{array}$ & $\begin{array}{c}-0.024 \\
(1.31)\end{array}$ & $\begin{array}{c}-0.045 \\
(1.42)\end{array}$ & $\begin{array}{c}-0.024 \\
(1.05)\end{array}$ \\
\hline
\end{tabular}

Notes: ${ }^{a}$ Non-manuals in engineering. See also notes to Table 4. 
Table 9. Tests for robustness and heterogeneity, hirings and separations, non-manual workers in engineering. Reform effects

\begin{tabular}{|c|c|c|c|c|c|c|}
\hline & $(1)$ & $(2)$ & (3) & (4) & (5) & (6) \\
\hline & & Hirings & & & $\overline{\text { Separations }}$ & \\
\hline & 1998-01 & 1998-02 & 1998-03 & 1998-01 & 1998-02 & 1998-03 \\
\hline Benchmark (Table 5) & $\begin{array}{c}0.045^{* * *} \\
(3.06)\end{array}$ & $\begin{array}{c}0.043^{* * *} \\
(3.01)\end{array}$ & $\begin{array}{c}0.054^{* * *} \\
(5.07)\end{array}$ & $\begin{array}{c}0.025^{* * *} \\
(2.87)\end{array}$ & $\begin{array}{c}0.037^{* * *} \\
(5.27)\end{array}$ & $\begin{array}{c}0.038^{* * *} \\
(4.67)\end{array}$ \\
\hline \multicolumn{7}{|l|}{ Subgroups } \\
\hline \multicolumn{7}{|l|}{ Age: } \\
\hline $18-24$ / 45-64 & $\begin{array}{c}0.085^{* * *} \\
(3.20)\end{array}$ & $\begin{array}{c}0.080^{* * *} \\
(3.16)\end{array}$ & $\begin{array}{c}0.077^{* * *} \\
(3.15)\end{array}$ & $\begin{array}{c}0.036^{* *} \\
(2.48)\end{array}$ & $\begin{array}{c}0.034^{* * *} \\
(2.78)\end{array}$ & $\begin{array}{l}0.022^{*} \\
(1.72)\end{array}$ \\
\hline 30-34 / 45-64 & $\begin{array}{l}0.013 \\
(1.32)\end{array}$ & $\begin{array}{c}0.021^{* * * *} \\
(2.66)\end{array}$ & $\begin{array}{c}0.020^{* *} \\
(2.53)\end{array}$ & $\begin{array}{c}0.014^{* *} \\
(2.20)\end{array}$ & $\begin{array}{c}0.024^{* * *} \\
(4.27)\end{array}$ & $\begin{array}{c}0.027^{* * *} \\
(4.75)\end{array}$ \\
\hline 35-39 / 45-64 & $\begin{array}{l}0.004 \\
(0.60)\end{array}$ & $\begin{array}{l}0.010 \\
(1.56)\end{array}$ & $\begin{array}{c}0.012^{* *} \\
(2.02)\end{array}$ & $\begin{array}{l}0.001 \\
(0.17)\end{array}$ & $\begin{array}{c}0.012^{* *} \\
(2.22)\end{array}$ & $\begin{array}{c}0.015^{* * *} \\
(3.07)\end{array}$ \\
\hline $40-44 / 45-64$ & $\begin{array}{l}0.005 \\
(0.73)\end{array}$ & $\begin{array}{l}0.009 \\
(1.57)\end{array}$ & $\begin{array}{c}0.010^{* *} \\
(2.20)\end{array}$ & $\begin{array}{c}-0.006 \\
(0.12)\end{array}$ & $\begin{array}{l}0.005 \\
(1.25)\end{array}$ & $\begin{array}{c}0.009^{* *} \\
(2.55)\end{array}$ \\
\hline $25-29 / 45-59$ & $\begin{array}{c}0.045^{* * *} \\
(3.06)\end{array}$ & $\begin{array}{c}0.043^{* * *} \\
(3.01)\end{array}$ & $\begin{array}{c}0.054^{* * * *} \\
(5.03)\end{array}$ & $\begin{array}{c}0.025^{* * * *} \\
(2.92)\end{array}$ & $\begin{array}{c}0.037^{* * *} \\
(5.21)\end{array}$ & $\begin{array}{c}0.038^{* * *} \\
(4.73)\end{array}$ \\
\hline Firm size: & & & & & & \\
\hline $1-49$ & $\begin{array}{l}0.023 \\
(0.43)\end{array}$ & $\begin{array}{l}0.018 \\
(0.39)\end{array}$ & $\begin{array}{l}0.015 \\
(0.34)\end{array}$ & $\begin{array}{l}-0.017 \\
(0.62)\end{array}$ & $\begin{array}{c}-0.014 \\
(0.56)\end{array}$ & $\begin{array}{c}-0.020 \\
(0.89)\end{array}$ \\
\hline$\geq 50$ & $\begin{array}{c}0.045^{* * *} \\
(3.03)\end{array}$ & $\begin{array}{c}0.043^{* * *} \\
(2.96)\end{array}$ & $\begin{array}{c}0.054^{* * *} \\
(5.04)\end{array}$ & $\begin{array}{c}0.025^{* * *} \\
(2.86)\end{array}$ & $\begin{array}{c}0.038^{* * *} \\
(5.23)\end{array}$ & $\begin{array}{c}0.039^{* * *} \\
(4.66)\end{array}$ \\
\hline $\begin{array}{c}\text { Additional variables } \\
\text { Age-specific } \\
\text { unemployment }\end{array}$ & $\begin{array}{c}0.030^{* *} \\
(2.08)\end{array}$ & $\begin{array}{c}0.035^{* *} \\
(2.40)\end{array}$ & $\begin{array}{c}0.054^{* * *} \\
(5.04)\end{array}$ & $\begin{array}{l}0.006 \\
(0.46)\end{array}$ & $\begin{array}{c}0.022^{* *} \\
(2.33)\end{array}$ & $\begin{array}{c}0.027^{* * *} \\
(3.33)\end{array}$ \\
\hline Trend x Age 45-64 & $\begin{array}{l}0.017 \\
(1.04)\end{array}$ & $\begin{array}{l}0.012 \\
(0.72)\end{array}$ & $\begin{array}{c}0.037^{* * *} \\
(2.81)\end{array}$ & $\begin{array}{c}0.032^{* * *} \\
(2.74)\end{array}$ & $\begin{array}{c}0.060^{* * *} \\
(5.04)\end{array}$ & $\begin{array}{c}0.062^{* * *} \\
(4.90)\end{array}$ \\
\hline
\end{tabular}

Note: See notes to Table 4. 
Table 10. Tests for robustness and heterogeneity, hirings and separations, manual workers in retail. Reform effects

\begin{tabular}{c|ccc|ccc}
\hline & $(1)$ & $(2)$ & $(3)$ & $(4)$ & $(5)$ & $(6)$ \\
\hline & & Hirings & & & Separations & \\
& $1998-02$ & $1998-03$ & $1998-04$ & $1998-02$ & $1998-03$ & $1998-04$ \\
Benchmark (Table 6) & $0.018^{*}$ & $0.034^{* * *}$ & $0.044^{* * *}$ & $0.047^{* * *}$ & $0.054^{* * *}$ & $0.057^{* * *}$ \\
& $(1.78)$ & $(3.01)$ & $(4.29)$ & $(8.17)$ & $(10.12)$ & $(11.36)$ \\
Subgroups & & & & & & \\
Age: & & & & & & \\
18-24 / 45-64 & $0.057^{* * *}$ & $0.081^{* * *}$ & $0.096^{* * *}$ & $0.085^{* * *}$ & $0.099^{* * *}$ & $0.112^{* * *}$ \\
& $(6.62)$ & $(8.04)$ & $(10.80)$ & $(7.52)$ & $(12.07)$ & $(13.82)$ \\
30-34 / 45-64 & $0.028^{* * *}$ & $0.029^{* * *}$ & $0.033^{* * *}$ & $0.025^{* * *}$ & $0.028^{* * *}$ & $0.031^{* * *}$ \\
& $(3.35)$ & $(3.39)$ & $(4.05)$ & $(5.52)$ & $(7.80)$ & $(9.61)$ \\
35-39 / 45-64 & $0.012^{*}$ & $0.023^{* * *}$ & $0.028^{* * *}$ & $0.018^{* * *}$ & $0.018^{* * *}$ & $0.022^{* * *}$ \\
& $(1.92)$ & $(3.30)$ & $(5.08)$ & $(4.65)$ & $(5.07)$ & $(7.23)$ \\
40-44 / 45-64 & $0.012^{* *}$ & $0.017^{* * *}$ & $0.016^{* * *}$ & $0.008^{* *}$ & $0.009^{* * *}$ & $0.009^{* * *}$ \\
& $(2.02)$ & $(3.24)$ & $(3.58)$ & $(2.19)$ & $(3.31)$ & $(3.75)$ \\
25-29 / 45-59 & $0.017^{*}$ & $0.034^{* * *}$ & $0.041^{* * * *}$ & $0.046^{* * *}$ & $0.053^{* * *}$ & $0.057^{* * *}$ \\
& $(1.65)$ & $(3.01)$ & $(4.07)$ & $(7.86)$ & $(10.08)$ & $(11.30)$ \\
Firm size: & & & & & & \\
1-49 & 0.042 & 0.038 & 0.037 & $0.063^{* * *}$ & $0.072^{* * *}$ & $0.064^{* * *}$ \\
& $(1.24)$ & $(1.40)$ & $(1.45)$ & $(2.74)$ & $(3.86)$ & $(3.75)$ \\
$\geq 50$ & $0.018^{*}$ & $0.034^{* * *}$ & $0.044^{* * *}$ & $0.046^{* * *}$ & $0.053^{* * *}$ & $0.057^{* * *}$ \\
& $(1.70)$ & $(2.90)$ & $(4.20)$ & $(7.78)$ & $(9.67)$ & $(10.97)$ \\
& & & & & & \\
Additional variables & & & & & & \\
Age-specific & $0.017^{*}$ & $0.025^{* *}$ & $0.025^{* *}$ & $0.037^{* * *}$ & $0.048^{* * *}$ & $0.057^{* * *}$ \\
unemployment & $(1.74)$ & $(2.33)$ & $(2.32)$ & $(5.72)$ & $(6.78)$ & $(9.80)$ \\
& & & & & & \\
Trend x Age 45-64 & 0.006 & 0.016 & $0.057^{* * *}$ & $0.052^{* * *}$ & $0.060^{* * *}$ & $0.069^{* * *}$ \\
& $(0.40)$ & $(0.95)$ & $(4.08)$ & $(5.30)$ & $(5.90)$ & $(7.98)$ \\
\hline & & & & & & \\
\hline
\end{tabular}

Note: See notes to Table 4. 
Table 11. Placebo tests for hiring and separations. Reform effects in "wrong” agreements.

\begin{tabular}{l|ccc|ccc}
\hline & $(1)$ & $(2)$ & $(3)$ & $(4)$ & $(5)$ & $(6)$ \\
\hline & \multicolumn{3}{|c}{ Hirings } & \multicolumn{3}{c}{ Separations } \\
Placebo reform 1997: & $1994-97$ & $1994-98$ & $1994-99$ & $1994-97$ & $1994-98$ & $1994-99$ \\
Retail, manuals & $-0.018^{*}$ & $-0.054^{* * *}$ & $-0.073^{* * *}$ & 0.012 & $-0.013^{*}$ & $-0.011^{*}$ \\
& $(1.79)$ & $(5.24)$ & $(7.38)$ & $(1.61)$ & $(1.76)$ & $(1.80)$ \\
Engineering, non- & $0.034^{* *}$ & -0.010 & 0.009 & 0.011 & $-0.012^{*}$ & -0.008 \\
manuals & $(1.97)$ & $(0.56)$ & $(0.53)$ & $(1.16)$ & $(1.72)$ & $(1.40)$ \\
& & & & & & \\
\hline
\end{tabular}

Note: See notes to Table 4.

Table 12. Placebo tests for hiring and separations. Reform effects in "wrong" years.

\begin{tabular}{|c|c|c|c|c|c|c|}
\hline & (1) & $(2)$ & (3) & (4) & (5) & (6) \\
\hline $\begin{array}{l}\text { Placebo reform year: } \\
\text { Engineering, manuals }\end{array}$ & $(t-3)-t$ & $\begin{array}{c}\text { Hirings } \\
(\mathrm{t}-3)-(\mathrm{t}+1)\end{array}$ & $(t-3)-(t+2)$ & $(t-3)-t$ & $\begin{array}{l}\text { Separations } \\
(\mathrm{t}-3)-(\mathrm{t}+1)\end{array}$ & $(\mathrm{t}-3)-(\mathrm{t}+2)$ \\
\hline 1995 & $\begin{array}{c}-0.087^{* * *} \\
(4.31)\end{array}$ & $\begin{array}{l}-0.058^{* * *} \\
(6.79)\end{array}$ & - & $\begin{array}{l}0.019^{*} \\
(1.83)\end{array}$ & $\begin{array}{l}0.018^{* * *} \\
(2.59)\end{array}$ & - \\
\hline 1996 & $\begin{array}{c}-0.002 \\
(0.14)\end{array}$ & - & - & $\begin{array}{l}0.010 \\
(1.40)\end{array}$ & - & - \\
\hline \multicolumn{7}{|l|}{$\begin{array}{l}\text { Engineering, non- } \\
\text { manuals }\end{array}$} \\
\hline 1995 & $\begin{array}{l}-0.109^{* * *} \\
(3.63)\end{array}$ & $\begin{array}{c}-0.133^{* * *} \\
(9.73)\end{array}$ & $\begin{array}{c}-0.114^{* * *} \\
(7.42)\end{array}$ & $\begin{array}{c}-0.032^{* * *} \\
(3.56)\end{array}$ & $\begin{array}{c}-0.019^{* * *} \\
(2.62)\end{array}$ & $\begin{array}{c}-0.009 \\
(1.13)\end{array}$ \\
\hline 1996 & $\begin{array}{c}-0.100^{* * *} \\
(3.64)\end{array}$ & $\begin{array}{c}-0.065^{* *} \\
(2.31)\end{array}$ & $\begin{array}{c}-0.084^{* * *} \\
(3.04)\end{array}$ & $\begin{array}{c}-0.005 \\
(0.62)\end{array}$ & $\begin{array}{l}0.004 \\
(0.46)\end{array}$ & $\begin{array}{c}-0.011 \\
(1.62)\end{array}$ \\
\hline 1998 & $\begin{array}{c}-0.057^{* * *} \\
(2.81)\end{array}$ & $\begin{array}{c}-0.009 \\
(0.57)\end{array}$ & $\begin{array}{c}-0.009 \\
(0.69)\end{array}$ & $\begin{array}{c}-0.034^{* * *} \\
(3.63)\end{array}$ & $\begin{array}{c}-0.017^{* *} \\
(2.32)\end{array}$ & $\begin{array}{c}-0.012 \\
(1.57)\end{array}$ \\
\hline 1999 & $\begin{array}{c}0.059^{* * *} \\
(4.10)\end{array}$ & $\begin{array}{c}0.033^{* * *} \\
(2.60)\end{array}$ & - & $\begin{array}{l}0.006 \\
(0.64)\end{array}$ & $\begin{array}{l}0.004 \\
(0.36)\end{array}$ & - \\
\hline 2000 & $\begin{array}{c}-0.018 \\
(1.22)\end{array}$ & - & - & $\begin{array}{l}0.001 \\
(0.05)\end{array}$ & - & - \\
\hline \multicolumn{7}{|l|}{ Retail, manuals } \\
\hline 1995 & $\begin{array}{c}-0.009 \\
(0.66)\end{array}$ & $\begin{array}{c}-0.014 \\
(1.09)\end{array}$ & $\begin{array}{l}-0.017 \\
(1.42)\end{array}$ & $\begin{array}{c}-0.058^{* * *} \\
(4.95)\end{array}$ & $\begin{array}{l}-0.032^{* * *} \\
(3.76)\end{array}$ & $\begin{array}{l}-0.026^{* * *} \\
(3.20)\end{array}$ \\
\hline 1996 & $\begin{array}{l}-0.028^{* *} \\
(2.17)\end{array}$ & $\begin{array}{c}-0.028^{* * *} \\
(2.80)\end{array}$ & $\begin{array}{c}-0.053^{* * *} \\
(5.01)\end{array}$ & $\begin{array}{l}0.016 \\
(1.03)\end{array}$ & $\begin{array}{l}0.013 \\
(1.09)\end{array}$ & $\begin{array}{c}-0.004 \\
(0.38)\end{array}$ \\
\hline 1998 & $\begin{array}{c}-0.070^{* * *} \\
(6.56)\end{array}$ & $\begin{array}{c}-0.084^{* * *} \\
(9.45)\end{array}$ & $\begin{array}{c}-0.085^{* * *} \\
(10.59)\end{array}$ & $\begin{array}{c}-0.030^{* * *} \\
(3.60)\end{array}$ & $\begin{array}{l}-0.019^{* * *} \\
(2.70)\end{array}$ & $\begin{array}{c}-0.018^{* * *} \\
(2.72)\end{array}$ \\
\hline 1999 & $\begin{array}{c}-0.070^{* * * *} \\
(6.38)\end{array}$ & $\begin{array}{c}-0.064^{* * *} \\
(6.85)\end{array}$ & - & $\begin{array}{c}-0.006 \\
(0.73)\end{array}$ & $\begin{array}{c}-0.011 \\
(1.62)\end{array}$ & - \\
\hline 2000 & $\begin{array}{c}-0.026^{* *} \\
(2.05)\end{array}$ & - & - & $\begin{array}{l}-0.007 \\
(0.91)\end{array}$ & - & - \\
\hline
\end{tabular}

Note: See notes to Table 4. 


\title{
APPENDIX
}

Table A.1. Terms of advance notice for employer-initiated separations in selected collective agreements, 1995-2005

a) Engineering (ISIC codes: 28-35)

\begin{abstract}
I. Manual workers
Agreements do not say anything specific about terms of advance notice, hence Employment Protection Act and changes therein apply throughout the period.
\end{abstract}

II. Non-manual workers

Agreements specify terms of notice supplanting Employment Protection Act throughout the period. Terms are both less stringent and more stringent than Act, depending on age and tenure of the employee.

1. - 31 March 1995*:

\begin{tabular}{lllllll|}
\hline Tenure / Age (years) & $<25$ & $25-29$ & $30-34$ & $35-39$ & $40-44$ & $\geq 45$ \\
\hline$<6$ months & 1 & 1 & 1 & 1 & 1 & 1 \\
6 months -6 years & 1 & 2 & 3 & 4 & 5 & 6 \\
$6-9$ years & 2 & 3 & 4 & 5 & 5 & 6 \\
$9-12$ years & - & 3 & 4 & 5 & 6 & 6 \\
\hline$>12$ years & - & 3 & 4 & 6 & 6 & 6 \\
\hline
\end{tabular}

* Tenure is calculated as specified in the Employment Protection Act. If the dismissal is due to lack of work, the employer must follow the terms of notice specified in special employment protection schemes (omställningsavtal).

2. 1 April 1995 - 31 January 2001:

The rules as in 1) applies, with the addendum that the notice period should be extended by 6 months for employees who at the time of notice, which should be due to lack of work, have reached the age of 55 and have been employed for the 10 latest consecutive years.

3. 1 February 2001- :

For employment contracts signed before 1 February 2001, 1) applies, with addendum in 2). For contracts signed after this date, same rules as in new Employment Protection Act (see Table 1, part II, with addendum in 2). 


\section{b) Construction}

I. Manual workers

Rules and dates of implementation in the three agreements in the construction sector are similar, but not identical. Rules have been less stringent than or identical to Employment Protection Act, depending on period and age of employee.

a) Building Agreement (Byggnadsavtalet)

ISIC codes: 45110, 45120, 45211, 45212, 45229, 45250, 45320, 45340, 45410, 45420, 45450, 45500

ISIC codes unique to agreement: 45110, 45211, 45229, 45320, 45340, 45410, 45420, 45450

1. - 31 March 2000

1 month if age is 25 or younger

2 months if age is 25 to $35^{*}$

4 months if age is 35 to $44^{*}$

6 months if age is 45 or older*

* Applies to employees with a permanent contract who at the time of notice have been employed by the same firm for (i) at least 12 months in total during the latest 2 years, or in case of employees at least 45 years old (ii) the latest 6 consecutive months.

2. 1 April $2000-$

Same rules as in new Employment Protection Act for employment contracts signed 1 July 1997 or later (see Table 1, part II). For employment contracts signed before this date, rules in old agreement (see a.1) apply.

b) Construction (except buildings) Agreement (Anläggningsavtalet)

ISIC codes: 45120, 45212, 45230, 45240, 45250, 45500

ISIC codes unique to agreement: 45240

1. - 31 March 2001

Same rules as in Construction Agreement (see a.1)

2. 1 April $2001-$

Same rules as in Construction Agreement (see a.2).

c) Road and Rail Construction Agreement (Avtalet för väg och ban)

ISIC codes: 45120, 45230, 45500

ISIC codes unique to agreement: None

1. - 31 March 2000

Same rules as in Construction Agreement (see a.1).

2. 1 April $2000-$

Same rules as in new Employment Protection Act for employment contracts signed 1 November 1997 or later (see Table 1, part II). For employment contracts signed before this date, rules in old agreement (see a.1) apply.

II. Non-manual workers

1. - 31 March 1998

Same rules as for non-manual workers in Engineering Agreement (see Table 2c, part II, 1).

\section{1 April $1998^{-}$}

Same rules as in new Employment Protection Act for employment contracts signed 1 April 1998 or later (see Table 1, part II). For contracts signed before this date, old rules apply as long as these imply a longer period of notice (see 1). Same addendum as for non-manual workers in Engineering Agreement applies to both new and old rules (see Table 2c, part II, 2). 
c) Retail (ISIC codes: 50-52)

I. Manual workers

There are many agreements in this sector: Retail Trade Agreement (Detaljhandelsavtalet), Wholesale Trade Agreement (Partihandelsavtalet) and other sector-specific agreements. Most agreements apply same rules regarding advance notice, namely those of Employment Protection Act (with delayed implementation).*

* An exception is restaurant workers in the retail sector, who are covered by separate agreement with Hotel and Restaurant Workers' Union (Hotell- och restaurangavtalet).

1. - 30 June 2001

Same rules as in old Employment Protection Act (see Table 1, part I).*

* Applies to employees with a permanent contract who at the time of notice have been employed by the same firm for (i) at least 12 months in total during the latest 2 years or (ii) the latest 6 consecutive months.

2. 1 July $2001-$

Same rules as in new Employment Protection Act for employment contracts signed 1 July 2001 or later (see Table 1, part II). For contracts signed before this date, 1) applies.

II. Non-manual workers

There are many agreements in this sector, with different rules regarding advance notice. Many workers are covered by agreement below, Tjänstemannaavtalet HTF.

1. -31 December 1997

Same rules as for non-manual workers in Engineering Agreement (see Table 2c, part II, 1 and addendum in 2).

2. 1 January $1998-$

Same rules as in new Employment Protection Act for employment contracts signed 1 January 1998 or later (see Table 1, part II). For contracts signed before this date, 1) applies

Source: See Table 2. 
Table A2. Variable definitions

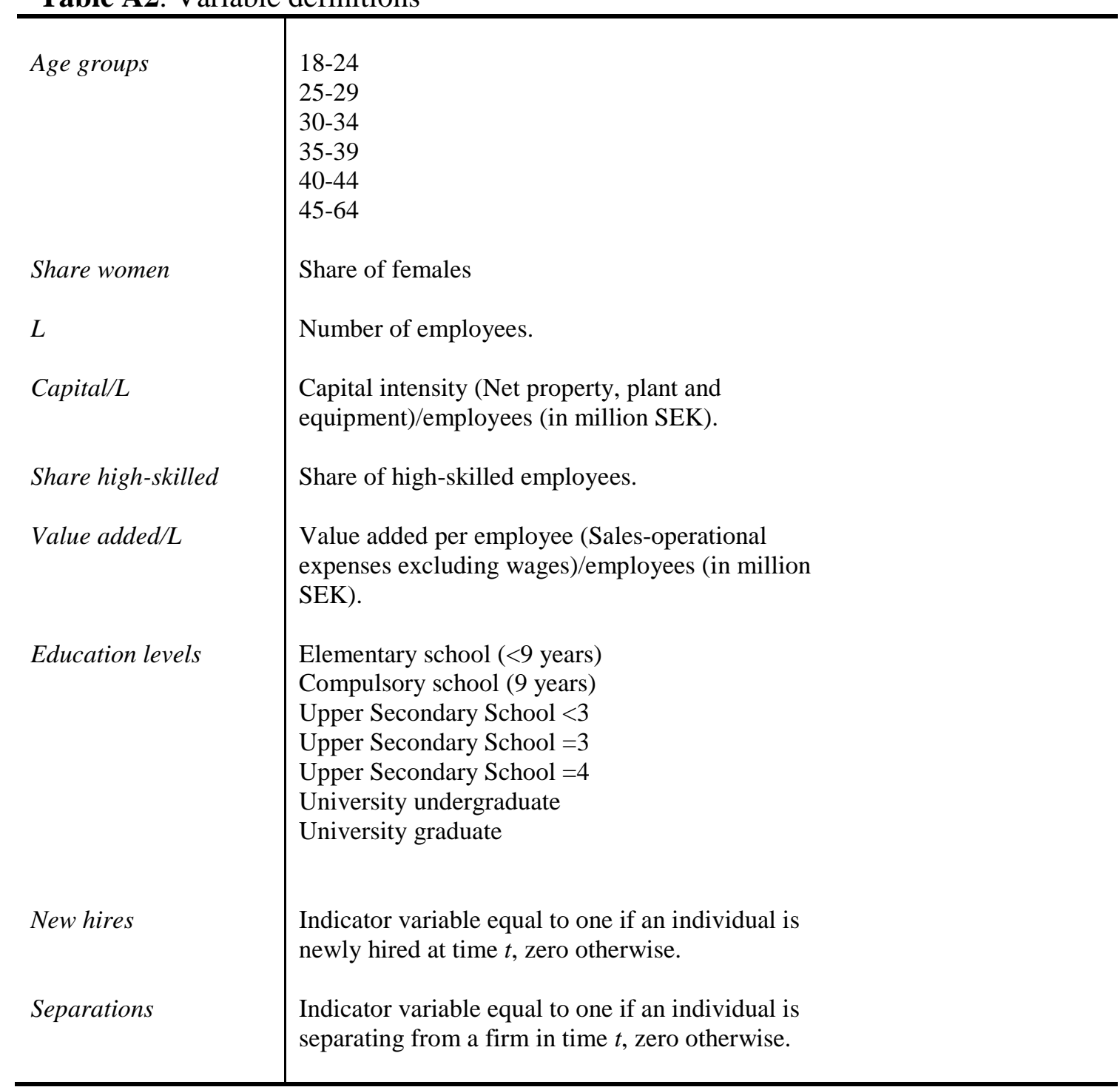


Table A3. Descriptive statistics, $(\mathrm{t}-3)-(\mathrm{t}+3)$

\section{Manuals in engineering}

Non-manuals in

Manuals in retail

engineering

\begin{tabular}{|c|c|c|c|c|c|c|}
\hline & Mean & St. Dev. & Mean & St. Dev. & Mean & St. Dev. \\
\hline Age group 18-24 & 0.115 & $(0.319)$ & 0.019 & $(0.138)$ & 0.277 & $(0.448)$ \\
\hline Age group 25-29 & 0.157 & $(0.363)$ & 0.113 & $(0.316)$ & 0.157 & $(0.364)$ \\
\hline Age group 30-34 & 0.159 & $(0.365)$ & 0.160 & $(0.366)$ & 0.128 & $(0.335)$ \\
\hline Age group 35-39 & 0.126 & $(0.332)$ & 0.161 & $(0.368)$ & 0.106 & $(0.308)$ \\
\hline Age group 40-44 & 0.114 & $(0.318)$ & 0.128 & $(0.334)$ & 0.079 & $(0.270)$ \\
\hline Age group 45-64 & 0.329 & $(0.470)$ & 0.419 & $(0.493)$ & 0.251 & $(0.434)$ \\
\hline New hires & 0.109 & $(0.312)$ & 0.125 & $(0.331)$ & 0.247 & $(0.431)$ \\
\hline Separations & 0.057 & $(0.232)$ & 0.070 & $(0.255)$ & 0.091 & $(0.287)$ \\
\hline Elementary School <9 & 0.162 & $(0.369)$ & 0.022 & $(0.147)$ & 0.089 & $(0.285)$ \\
\hline Compulsory School =9 & 0.182 & $(0.386)$ & 0.044 & $(0.204)$ & 0.175 & $(0.380)$ \\
\hline Upper Secondary School <3 & 0.441 & $(0.497)$ & 0.180 & $(0.384)$ & 0.316 & $(0.465)$ \\
\hline Upper Secondary School =3 & 0.196 & $(0.397)$ & 0.382 & $(0.486)$ & 0.366 & $(0.482)$ \\
\hline Upper Secondary School =4 & 0.013 & $(0.113)$ & 0.067 & $(0.249)$ & 0.027 & $(0.162)$ \\
\hline University undergraduate & 0.006 & $(0.077)$ & 0.289 & $(0.453)$ & 0.027 & $(0.162)$ \\
\hline University graduate & 0.000 & $(0.013)$ & 0.016 & $(0.126)$ & 0.000 & $(0.011)$ \\
\hline Log firm size & 7.637 & $(1.487)$ & 7.582 & $(1.556)$ & 7.069 & $(1.681)$ \\
\hline Share of high-skilled & 0.216 & $(0.123)$ & 0.355 & $(0.186)$ & 0.127 & $(0.069)$ \\
\hline Share women & 0.228 & $(0.110)$ & 0.241 & $(0.105)$ & 0.574 & $(0.256)$ \\
\hline Value added/L & 0.516 & $(0.301)$ & 0.574 & $(0.674)$ & 0.440 & $(0.234)$ \\
\hline Capital/L & 0.269 & $(0.225)$ & 0.252 & $(0.243)$ & 0.195 & $(0.277)$ \\
\hline Number of observations & \multicolumn{2}{|c|}{428,757} & \multicolumn{2}{|c|}{338,440} & \multicolumn{2}{|c|}{407,352} \\
\hline
\end{tabular}

Notes: Figures are based on the same sample of workers and firms as in the regression analysis. See the data section in the text for details. 


\section{ENDNOTES}

${ }^{1}$ See the extensive surveys of employment protection research by Skedinger (2010 and 2011). Studies on job and worker flows based on partial reforms targeted towards small (or large) firms include von Below and Skogman Thoursie (2010), Kugler and Pica (2008), Martins (2009) and Schivardi and Torrini (2008). See Feldmann (2003) for an example of a cross-country study on the impact of employment protection.

${ }^{2}$ Cappellari, Dell'Aringa and Leonardi (2012), exploits the similarly staggered structure of collective agreements in Italy to examine the effects of fixed-term employment and apprenticeship reforms on job reallocation and productivity, but do not identify effects through partial reform, as defined by us.

${ }^{3}$ Individual agreements are also allowed on the condition that the periods of notice are longer than those specified by law and that the agreement is not in conflict with a collective agreement that the employer and the employee are bound by.

${ }^{4}$ Legal interpretation of changes in EPA seems to be more uncertain, however, in agreements stating that the rules are "complements to the EPA" (see the discussion in the annual report of the National Mediation Office, 2009). There are no such formulations in the agreements considered by us. For more information on procedural rules regarding implementation in collective agreements, see the working paper version of this article (Heyman and Skedinger, 2011).

${ }^{5}$ Table A.3 in the Appendix presents descriptive statistics on age and other characteristics for workers in different collective agreements.

${ }^{6}$ This differs from the interpretation of Heckman and Pagés-Serra (2000) in which the factors $1-a$ and a are introduced in reverse order as compared with our equation and a is the probability that the "economic difficulties" of the firm are considered as a justified cause for dismissal. We have chosen an interpretation more relevant to the Swedish context, since economic difficulties are always accepted as a just cause for dismissal and the associated severance pay $\left(S^{j c}\right)$ is zero, implying that this term drops out of the equation.

However, the absence of severance pay for such dismissals does not imply that it is an optimal strategy for the firm to always justify their layoffs as being due to economic difficulties, since the firm runs the risk of having a discharge declared wrongful by a court, with severance pay in the form of damages awarded to the dismissed worker. This could happen if the court finds that the worker actually was laid off for (invalid) personal reasons rather than economic difficulties. It could also be the case that the court finds that the firm selected the 'wrong' worker for dismissal for economic reasons, without proper consideration of the seniority rules that are stipulated by law.

${ }^{7}$ The equivalence between advance notice and real firing costs for the firm may be questioned, since the dismissed worker is supposed to work during the notice period. In Sweden, the worker has a legal right to the usual salary from the time of notice, regardless of whether the employer has any job to offer and regardless of whether working time is reduced. Suffice for our analysis is that firing costs increase in the period of notice, which seems reasonable as presumably less of actual work, in relation to stipulated hours of work, is put in the longer the period of notice.

${ }^{8}$ The figures, based on data from the Bureau of Labor Statistics, are averages for both manual and nonmanual workers over the period 2001-05. Data were not available for engineering, so the figures for the manufacturing of durable goods have been used for this industry.

${ }^{9}$ For workers below the age of 60 , the so-called "special damages" for the case of a dismissal without just cause is 16 months of salary for workers with less than 5 years tenure, 24 months of salary for workers with at least 5 but less than 10 years tenure and 32 months of salary for workers with at least 10 years tenure. In addition, two age-dependent rules apply for special damages. First, for workers above the age of 60 , the corresponding damages are equivalent to 24,36 and 48 months of salaries, respectively. Secondly, workers at least 45 years of age are entitled to count each month of employment past that age as 2 months, up to a maximum of 60 such extra months. This rule also applies to workers above the age of 60 who are entitled to higher damages. Damages, in monthly salaries, cannot exceed the number of months employed unless the worker has been employed for less than six months in which case the damages amount to 6 months of salary. The court can also award "general damages" to the employee as compensation for psychological costs and non-payment of salary. General damages are not included in our computation of severance pay without just cause.

${ }^{10}$ Benefits in both schemes are available for workers dismissed due to the lack of work and are dependent on age and tenure. Non-manual workers receiving advance notice are entitled to counselling and coaching during the notice period. When the notice period has ended, the councils provide monetary compensation in the form of severance pay (manual workers) or supplements to unemployment insurance benefits (non-manual workers).

${ }^{11}$ Construction was excluded due to the lack of data of sufficient quality in that sector. 
${ }^{12}$ Note that we do not have a missing value if a worker has worked in another industry before being hired. The newly-hired indicator is equal to one if a worker is new in a firm, but was not employed in the firm the year before, irrespective of whether the newly hired worker was in another industry or not before being hired. The same applies to unemployment spells before being hired and to the identification of newly-separated employees. The focus is on newly-hired and newly-separated workers and how these groups differ between treated and non-treated individuals. Hence, we do not identify the effects on just workers that continually work in the same industry.

${ }^{13}$ More specifically, in our analysis on hirings, we omit firms with a hiring rate above 30 percent in combination with those having more than 100 new employees. For separations, we omit firms with (i) a separation rate above 30 percent in combination with observing at least 100 fewer employees or (ii) a separation rate above 50 percent. The results, available on request, are not qualitatively affected by these restrictions.

${ }^{14}$ See Heyman, Sjöholm and Gustavsson Tingvall $(2007,2011)$ for more information on the data.

${ }^{15}$ Pre-1997 trends for manual workers aged $45-64$ in retail (not shown in the figure) diverge substantially from those of manuals in engineering.

${ }^{16}$ Clustering by age group, the individual level or age group-year produced substantially larger $t$-values than those associated with clustering by firm. Clustering by firm-year resulted in nearly identical $t$ values as clustering by firm.

${ }^{17}$ This robustness check is similar to that undertaken by Bertrand and Mullainathan (1999). See also Angrist and Pischke (2009).

${ }^{18}$ This differs from studies of partial reforms based on firm size (discussed in Section 1) in which the exogeneity assumption may be questioned.

${ }^{19}$ When looking at the underlying variables in more detail we note that the median notice period of an individual worker is longer in the treated group (age 45-64) than in the control group (age 25-29) over the entire period. It is also the case that the workers' relative notice period is longer in the treated group. In addition, there is a higher correlation between the notice period and the relative notice period in the treated group. (Details are available upon request.)

${ }^{20}$ It is our preferred estimates because the firm panels entail a substantial loss of observations, between 24 and 38 percent, depending on the industry and worker category, in the specifications with the longest post-reform period.

${ }^{21}$ We have also experimented with a number of additional control variables: individual tenure (in the separations regressions), the share of manual workers at the firm, the share of 45 -64-year-olds at the firm and age as a continuous variable. The two firm variables are intended to pick up influences on turnover from the structure of the workforce (i.e., if firms with relatively many older workers are more inclined to hire such workers). These exercises produced small changes in the results (as did including tenure in the regressions in Table 7). Experiments with extending the pre-reform period to four or five years did not change the results substantially, but the effect on hirings turned insignificant in the latter specification. These results may however be affected by the deep financial crisis in the early 1990s. Robustness with regard to gender was examined by running separate regressions for males and females. For hirings, the estimates are consistently larger for males but are insignificant beyond the initial evaluation period. The estimates for separations are insignificant without exception. Finally, experiments with probit estimations yielded conclusions identical to those with OLS.

${ }^{22}$ Bergström and Panas (1992) find that manuals and non-manuals are substitutes in engineering, which supports our interpretation of the results for non-manuals.

${ }^{23}$ We performed the same robustness checks for non-manuals in engineering and manuals in retail as those for manuals in engineering, described in footnote 21 . The results were basically unchanged.

${ }^{24}$ An alternative to these placebo tests is to run regressions with year-specific reform effects, both before and after the reform. Significant pre-reform effects could imply violation of the parallel trend assumption. For non-manuals in engineering and manuals in retail, we find a significant reform effect in 1999 in some specifications, but otherwise little evidence of pre-reform effects. 